\title{
Variation in structure and biomass of the benthic communities at three contrasting sites in the tropical Northeast Atlantic
}

\author{
Joëlle Galéron ${ }^{1, *}$, Myriam Sibuet $^{1}$, Marie-Laure Mahaut ${ }^{2}$, Alain Dinet $^{3}$ \\ ${ }^{1}$ Département Environnement Profond, IFREMER Centre de Brest, BP 70, 29280 Plouzané, France \\ ${ }^{2}$ Intechmer, Digue de Collignon, BP 324, 50103 Cherbourg Cedex, France \\ ${ }^{3}$ Laboratoire Arago, 66650 Banyuls-Sur-Mer, France
}

\begin{abstract}
Three major size classes of the benthic metazoan communities (megafauna, macrofauna and meiofauna) were investigated simultaneously at 3 sites in the tropical Northeast Atlantic. The sites varied in their level of surface primary productivity (eutrophic, mesotrophic and oligotrophic). Results for 3 cruises in 3 seasons (Eumeli 2, winter 1991; Eumeli 3, autumn 1991; Eumeli 4, spring 1992) are given for each size class in terms of taxonomic composition, density and biomass. The benthic communities did not exhibit evidence of seasonal variation, but there were substantial differences in the quantitative structure of the metazoan communities between the 3 sites. Total metazoan density and biomass, as well as density and biomass of each size class, decreased with increasing depth and decreasing food supply, suggesting that food limitation is the major factor controlling benthic standing stocks. The comprehensive study across the 3 major benthic metazoan size classes reveals that each component responds differently to the variation in food input, leading to a variation in the quantitative structure of the benthic metazoan fauna. The largest size class, megafauna, dominated biomass when the food input was high (eutrophic site), macrofauna was predominant in intermediate conditions (mesotrophic site), and meiofauna dominated where the food input was the lowest and depth the greatest (oligotrophic site). However, within a single size group, some taxa did not follow the trend of decreasing biomass with decreasing food supply, suggesting that food availability is not the only factor governing the structure of the benthic fauna. The influence of abiotic and biotic factors likely to affect the benthic communities was analysed. Physical conditions and biological features can also play a significant role in structuring abyssal fauna.
\end{abstract}

KEY WORDS: Deep sea - Tropical Atlantic - Meiofauna - Macrofauna - Megafauna - Taxonomic composition · Density $\cdot$ Biomass $\cdot$ Environmental conditions

\section{INTRODUCTION}

Except in hot vent and cold seep ecosystems, deepsea communities are driven by energy derived from particulate organic matter sedimenting from surface waters. Since productivity decreases from shore to open oceanic regions, and the energy content of the vertical flux generally decreases with water depth (Rowe \& Staresinic 1979, Suess 1980), the total benthic

•E-mail: jgaleron@ifremer.fr standing stock decreases with both depth and distance from shore (Thiel 1975). As already shown for different benthic size classes (meiofauna, macrofauna, megafauna), there is a decrease in density and biomass as the food supply diminishes (Rowe 1971, Thiel 1983, Sibuet et al. 1984, 1989, Pfannkuche 1985, Sibuet 1987, Thurston et al. 1994, Vincx et al. 1994). The average size of benthic faunal components is known to decrease with increasing depth (Thiel 1975, Polloni et al. 1979, Schwinghamer 1981, Gage \& Tyler 1982, Romero-Wetzel \& Gerlach 1991, Vanreusel et al. 1995), though the size-depth pattern within species could 
reveal a trend for size to increase with depth, as recently shown by Rex \& Etter (1998) for deep-sea benthic gastropods. Quantitative information on the standing stocks of more than 1 size class of deep-sea benthos, sampled simultaneously in a single area, is limited (Sibuet et al. 1984, 1989, Richardson \& Young 1987, Pfannkuche 1992). Yet, this information is necessary to understand how energy is partitioned between the different components of the communities.

The benthic part of the Eumeli-JGOFS programme in the tropical Northeast Atlantic sought to study the benthic response to the vertical trophic flux induced by surface primary production (Sibuet et al. 1993), under contrasting conditions in a single geographical area. The Eumeli cruises provided a large sampling of the 3 major metazoan size classes of the deep-sea benthos (meiofauna, macrofauna and megafauna), in 3 different seasons (winter, autumn and spring), from 3 abyssal sites (eutrophic, mesotrophic and oligotrophic). The cruises provided simultaneously a large amount of valuable data on the trophic and physical environment at these 3 sites.

The objectives of this paper are (1) to describe the taxonomic structure, density, and biomass of the $3 \mathrm{ma}-$ jor size classes of the benthic communities (meiofauna, macrofauna and megafauna), (2) to investigate for the first time at low latitude and at great depth, potential temporal changes in the benthic fauna, (3) to compare the variation of the benthic communities in structure and biomass in 3 contrasting environmental settings, and (4) to discuss the observed variations in relation to abiotic and biotic factors. This study completes the preliminary Eumeli general results published in Sibuet et al. (1993), and the studies of macrofauna (Cosson et al. 1997) and meiofauna (Relexans et al. 1996).

\section{MATERIALS AND METHODS}

General description of study sites. The EumeliJGOFS benthic programme (Sibuet et al. 1993, Morel 1996) was carried out at 3 permanent deep-sea sites in the tropical Northeast Atlantic, along a west-east transect, north of the Cape Verde Rise, 19 to $21^{\circ} \mathrm{N}$, during 3 cruises: Eumeli 2 (January-February 1991), Eumeli 3 (September-October 1991) and Eumeli 4 (May-June 1992). These sites (Fig. 1) are characterized by steadystate sedimentation (Auffret et al. 1992) and contrasting surface primary production conditions (Morel 1996). The eutrophic site (Site E) is located $110 \mathrm{~km}$ off Cap Blanc (centred at $20^{\circ} 32^{\prime} \mathrm{N}, 18^{\circ} 32^{\prime} \mathrm{W}$ ), under the influence of seasonal upwelling (Morel 1996, Jorissen et al. 1998). It consists of a gently sioping sedimentary spur extending from $\sim 1600$ to $\sim 2100 \mathrm{~m}$ depth, over $150 \mathrm{~km}^{2}$. Surface sediments are greenish, marly, nannofossil sili- ceous oozes. The mesotrophic site (Site M), located on the Cape Verde Terrace, $\sim 500 \mathrm{~km}$ from the African coast, presents a particularly flat and homogeneous seafloor. It is centred at $18^{\circ} 30^{\prime} \mathrm{N}, 21^{\circ} 01^{\prime} \mathrm{W}$ and lies at a mean depth of $3110 \mathrm{~m}$. The surface sediments are greyish, marly, nannofossil oozes. The area studied covers $350 \mathrm{~km}^{2}$. The oligotrophic site (Site O), about $1650 \mathrm{~km}$ from the Mauritanian coast, is located on the Cape Verde abyssal plain, centred at $21^{\circ} 03^{\prime} \mathrm{N}$, $31^{\circ} 10^{\prime} \mathrm{W}$. The depth varies from 4480 to $4640 \mathrm{~m}$. The surface sediments are whitish nannofossil oozes and the interface is characterized by mud mounds and feeding traces. The area studied covers $200 \mathrm{~km}^{2}$.

The Eumeli programme provided a large amount of environmental data, from which we present a selection useful in this ecological study (Table 1). The annual primary production at the 3 sites was evaluated by Morel (1996), using a standard model (Morel et al. 1996). It varied from $500 \mathrm{~g} \mathrm{C} \mathrm{m}^{-2} \mathrm{yr}^{-1}$ at the shallowest site (Site E) to $120 \mathrm{~g} \mathrm{C} \mathrm{m}^{-2} \mathrm{yr}^{-1}$ at the deepest one (Site O). The primary production presented a strong seasonal variation at Site $E$ with a maximum in June-July. At Site $M$ temporal variations were also observed from April to October, with weaker signals. At Site $O$ the primary production was rather constant over the year. The annual particulate organic carbon (POC) flux values into the deep ocean were measured at Sites $O$ (Khripounoff et al. 1998) and M (A. Khripounoff unpubl. data), using sediment traps moored $200 \mathrm{~m}$ above the bottom. These values $\left(0.4\right.$ and $1.9 \mathrm{~g} \mathrm{C} \mathrm{m}^{-2} \mathrm{yr}^{-1}$ respectively at Sites $\mathrm{O}$ and $M$ ) were close to those calculated by Rabouille et al. (1993) (0.36 and $1.8 \mathrm{~g} \mathrm{C} \mathrm{m}^{-2} \mathrm{yr}^{-1}$ ). As flux data from sediment traps were not obtained at Site $\mathrm{E}$, we used calculated values $\left(6 \mathrm{~g} \mathrm{C} \mathrm{m}^{-2} \mathrm{yr}^{-1}\right)$ (Rabouille et al. 1993). Sedimentation rates and sediment $\mathrm{CaCO}_{3}$ values were evaluated by Auffret et al. (1992). The high value of $\mathrm{CaCO}_{3}$ in the sediment at Site $\mathrm{E}$ reflects the larger contribution of terrestrial material in the sediment, compared with the other sites. This terrestrial matter may be carried down the slope by bottom currents. This suggestion is supported by the high bottom current speeds in this area ( $\max .40 \mathrm{~cm} \mathrm{~s}^{-1}$, mean: $20 \mathrm{~cm} \mathrm{~s}^{-1}$ ) and currents directed down the slope (Vangriesheim 1995). The mixing layers and the bioturbation rates were obtained from ${ }^{210} \mathrm{~Pb}\left(t_{1 / 2}=22.3 \mathrm{yr}\right),{ }^{228} \mathrm{Th}\left(t_{1 / 2}=1.9 \mathrm{yr}\right)$, ${ }^{234} \mathrm{Th}\left(t_{1 / 2}=24.1 \mathrm{~d}\right)$ and ${ }^{137} \mathrm{Cs}\left(\mathrm{T}_{1 / 2}=30.2 \mathrm{yr}\right)$ profiles (Legeleux 1994). The mixing layers varied from $2-2.5 \mathrm{~cm}$ at Site $O$, to $3-4.5 \mathrm{~cm}$ at Site $\mathrm{M}$ and $10-12 \mathrm{~cm}$ at Site E. Sedimentation rates (from $0.5 \mathrm{~cm}$ per $1000 \mathrm{yr}$ at Site $O$, to $1.5 \mathrm{~cm}$ per $1000 \mathrm{yr}$ at Site $M$ and $4.4 \mathrm{~cm}$ per $1000 \mathrm{yr}$ at Site E) indicate that $0.5 \mathrm{~cm}$ of sediment represents from 100 to 1000 yr of sedimentation. If the penetration into the sediment of the different radionuclides resulted only from sedimentation, they should not be present deeper than the first millimeters, be- 


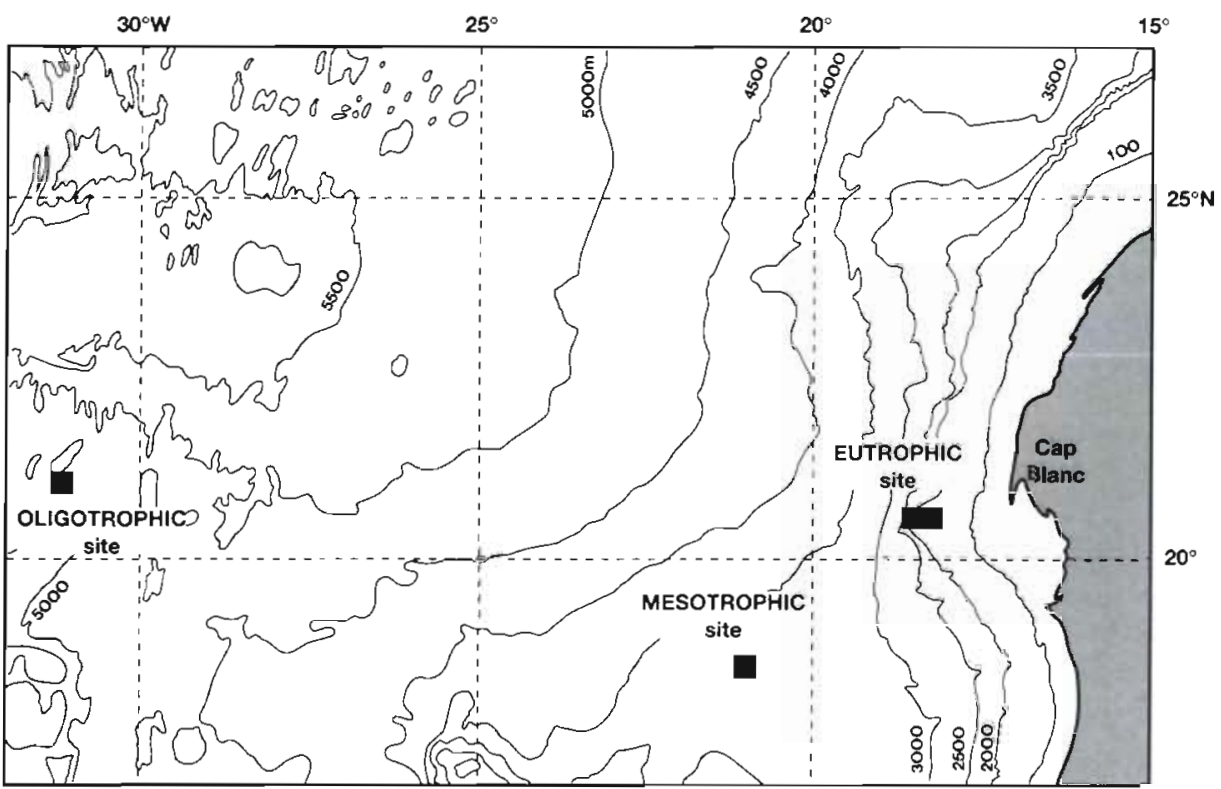

Fig. 1. Location of the 3 Eumeli sites in the tropical Northeast Atlantic

cause of their short periods $(<30 \mathrm{yr})$. The radionuclide profiles show that all the tracers, including ${ }^{234} \mathrm{Th}$, are present in the sediment, up to several centimeters deep. These results show that the vertical distribution of the radionuclides, and in turn the mixing layers, are directly linked to bioturbation (Legeleux et al. 1994).

Sampling strategy and sample processing. At all 3 sites, the benthic fauna was sampled with 3 different types of equipment in order to collect the major size classes: replicated multiple corer and box corer deployments provided meiofaunal and macrofaunal samples, while megafauna were collected using a beam trawl. Acoustic monitoring permitted the corer samples to be located on the bottom and the tracks of the trawl to be followed (Fig. 2). This study is based on the analysis of
31 subsamples (see following section for the method) from 5 multiple cores and 74 subsamples from 39 box cores for meiofauna, 49 box cores for macrofauna, and 16 beam trawl catches for megafauna. Details of the sampling are presented in Table 2. Site $\mathrm{E}$ was not investigated in autumn (Eumeli 3) and no megafaunal samples were obtained during spring (Eumeli 4).

Meiofauna. This category includes small metazoan organisms retained by a $40 \mu \mathrm{m}$ mesh sieve (Vitiello \& Dinet 1979). All taxa were counted, as usual in meiofaunal studies (Vincx et al. 1994), even when present in low numbers. Two types of corers were used to sample the meiofauna, a modified USNEL box corer (Hessler \& Jumars 1974), equipped with large top-flaps to minimize the bow-wave effect, and a SMBA multiple corer

Table 1. Environmental data from the 3 Eumeli sites. "Measured $10 \mathrm{~m}$ above the bottom at Sites $\mathrm{E}$ and $\mathrm{M}$, and $20 \mathrm{~m}$ above at Site $\mathrm{O}$. POC fluxes: (c) calculated, (m) measured

\begin{tabular}{|c|c|c|c|}
\hline & $\begin{array}{l}\text { Eutrophic site } \\
(1600-2100 \mathrm{~m})\end{array}$ & $\begin{array}{c}\text { Mesotrophic site } \\
(3110 \mathrm{~m})\end{array}$ & $\begin{array}{l}\text { Oligotrophic site } \\
(4640 \mathrm{~m})\end{array}$ \\
\hline Primary production $\left(\mathrm{g} C \mathrm{~m}^{-2} \mathrm{yr}^{-1}\right)^{a}$ & 500 & 320 & 120 \\
\hline POC flux ( $200 \mathrm{~m}$ above bottom) $\left(\mathrm{g} \mathrm{C} \mathrm{m}^{-2} \mathrm{yr}^{-1}\right)^{\mathrm{b}, c, \mathrm{~d}}$ & 6 (c) & $1.9(\mathrm{~m})$ & $0.4(\mathrm{~m})$ \\
\hline Sedimentation rate $(\mathrm{cm} \text { per } 1000 \mathrm{yr})^{\mathrm{e}}$ & 4.4 & 1.5 & 0.5 \\
\hline Bioturbation rate $\left(\mathrm{cm}^{2} \mathrm{~s}^{-1}\right)^{\mathrm{f}}$ & $50-200 \times 10^{-9}$ & $30-70 \times 10^{-9}$ & $0.3-0.6 \times 10^{-9}$ \\
\hline Mixing layer thickness $(\mathrm{cm})^{\mathrm{f}}$ & $10-12$ & $3-4.5$ & $2-2.5$ \\
\hline Sediment organic carbon $\left(\mathrm{mg} \mathrm{C} \mathrm{cm}^{-3}\right)^{c}$ & 12.6 & 2.2 & 1.6 \\
\hline Sediment $\mathrm{CaCO}_{3}(\%)^{\mathrm{e}}$ & 40 & 62 & 72 \\
\hline Temperature (bottom water) $\left({ }^{\circ} \mathrm{C}\right)^{\mathrm{g}}$ & $3.6-4.6$ & 2.7 & 2.4 \\
\hline Bottom current speed (mean) $\left(\mathrm{cm} \mathrm{s}^{-1}\right)^{\mathrm{h}}$. & 20 & 5 & 3 \\
\hline Bottom current speed $(\max .)\left(\mathrm{cm} \mathrm{s}^{-1}\right)^{\mathrm{h}}$ & 40 & 15 & 10 \\
\hline
\end{tabular}




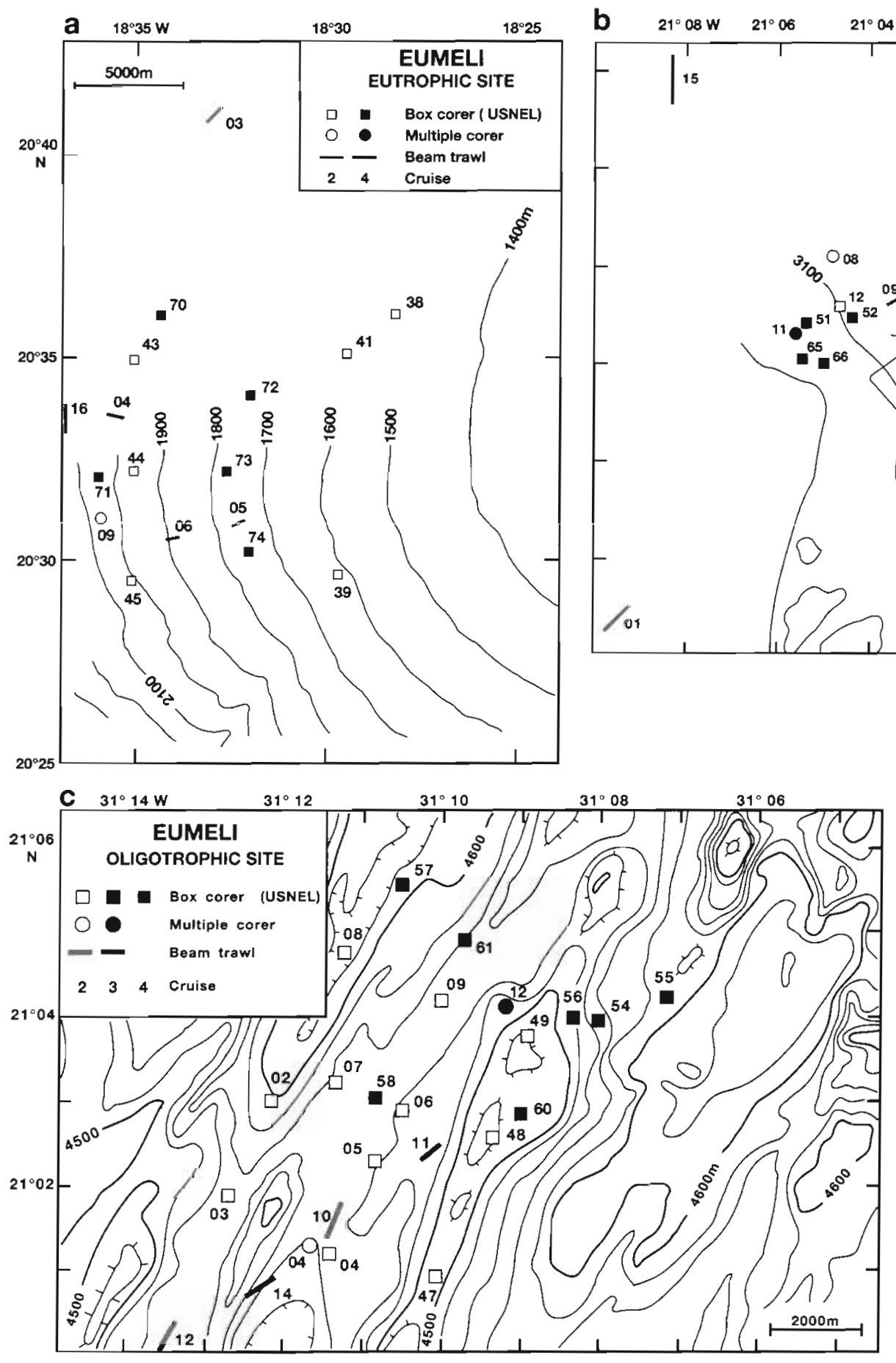

Fig. 2. Bathymetric maps and locations of the photographic surveys, trawl, box corer and multiple corer samples during the cruises Eumeli 2, 3 and 4 for the (a) eutrophic site, (b) mesotrophic site and (c) oligotrophic site

(Barnett et al. 1984) equipped with 12 tubes of $6 \mathrm{~cm}$ inner diameter. We checked that the overlying water of the cores was clear before performing our meiofauna sampling and rejected all the visibly disturbed sedimentary interfaces. The sediment was subsampled down to $5 \mathrm{~cm}$ depth with standard cores consisting of cut-off plastic syringes of $5.31 \mathrm{~cm}^{2}$ in area, preserved in $3 \%$ buffered formaldehyde and stained with Rose Bengal. Organisms were extracted by a centrifugation method adapted from de Jonge \& Bouwman (1977). The main taxa were nematodes and copepods, which together represented more than $95 \%$ of the total meiofaunal density. A total of 100 nematodes and 100 copepods were randomly sorted in one sample from Site $M$ for each of the 3 cruises to assess a mean individual wet weight through the biovolume method. Other rare taxa were not considered in evaluation of biomass, on the basis of their lower relative quantitative impor- 
Table 2. Source data of the Eumeli benthic programme: number of samples and sampled area for each size class of the benthic fauna at the 3 sites during the 3 cruises. For meiofauna, samples are subcores from box corer (b) or multiple corer (m)

\begin{tabular}{|c|c|c|c|c|c|c|c|}
\hline \multirow[t]{2}{*}{ Cruise } & \multirow[t]{2}{*}{ Size class } & \multicolumn{2}{|c|}{$\begin{array}{c}\text { Eutrophic site } \\
\text { Central position: } 20^{\circ} 30^{\prime} \mathrm{N}, 18^{\circ} 30^{\prime} \mathrm{W} \\
\text { Mean depth: } 1700 \mathrm{~m}\end{array}$} & \multicolumn{2}{|c|}{$\begin{array}{c}\text { Mesotrophic site } \\
\text { Central position: } 18^{\circ} 30^{\prime} \mathrm{N}, 21^{\circ} \mathrm{W} \\
\text { Mean depth: } 3100 \mathrm{~m}\end{array}$} & \multicolumn{2}{|c|}{$\begin{array}{c}\text { Oligotrophic site } \\
\text { Central position: } 21^{\circ} \mathrm{N}, 31^{\circ} \mathrm{W} \\
\text { Mean depth: } 4500 \mathrm{~m}\end{array}$} \\
\hline & & No. of samples & Total area $\left(\mathrm{m}^{2}\right)$ & No. of samples & Total area $\left(\mathrm{m}^{2}\right)$ & No. of samples & Total area $\left(\mathrm{m}^{2}\right)$ \\
\hline Eumeli 2 & Meiofauna & $12(b)$ & $63.72 \times 10^{-4}$ & $18(\mathrm{~b})$ & $95.58 \times 10^{-4}$ & $16(b)$ & $84.96 \times 10^{-4}$ \\
\hline (9 Jan - & & $2(\mathrm{~m})$ & $10.32 \times 10^{-4}$ & $5(\mathrm{~m})$ & $26.55 \times 10^{-4}$ & $10(\mathrm{~m})$ & $53.1 \times 10^{-4}$ \\
\hline $22 \mathrm{Feb}$ & Macrofauna & 7 & 1.75 & 16 & 4 & 9 & 2.25 \\
\hline 1991) & Megafauna & 4 & $1.138 \times 10^{4}$ & 5 & $2.68 \times 10^{4}$ & 3 & $1.493 \times 10^{4}$ \\
\hline Eumeli 3 & Meiofauna & & & $4(b)$ & $21.24 \times 10^{-4}$ & $5(b)$ & $26.55 \times 10^{-4}$ \\
\hline (14 Sep - & & & & $11(\mathrm{~m})$ & $58.41 \times 10^{-4}$ & $3(\mathrm{~m})$ & $15.93 \times 10^{-4}$ \\
\hline 4 Oct & Macrofauna & & & 2 & 0.5 & 5 & 1.25 \\
\hline 1991) & Megafauna & & & 1 & $0.275 \times 10^{4}$ & 1 & $0.467 \times 10^{4}$ \\
\hline Eumeli 4 & Meiofauna & 7 (b) & $37.17 \times 10^{-4}$ & 7 (b) & $37.17 \times 10^{-4}$ & $2(b)$ & $10.62 \times 10^{-4}$ \\
\hline (18 May - & Macrofauna & 4 & 1 & 4 & 1 & 2 & 0.5 \\
\hline 9 Jun 1992) & Megafauna & 1 & $0.225 \times 10^{4}$ & 1 & $0.385 \times 10^{4}$ & & \\
\hline
\end{tabular}

tance. The biomass in carbon was calculated assuming that the weight in carbon is equivalent to $13 \%$ of the wet (formalin) weight (Jensen 1984).

Meiofauna sampling efficiency was evaluated by Cosson (1996), who showed that the conditions required for a statistically reliable estimate of meiofaunal density were encountered at the 3 Eumeli sites during the 3 seasons, except at Site $E$ in spring, with only 2 samples. Differences in mean densities between samples obtained with both devices were analysed by a $t$-test. To assess temporal variations in mean densities within each site, $90 \%$ confidence intervals were calculated. Moreover, differences between data sets obtained from different seasons and different sites for total meiofauna, and the 2 dominant taxa (nematodes and copepods) were also analysed by $t$-tests. Biomass data could not be statistically analysed because biomass was evaluated by using a mean individual weight.

Macrofauna. Macrofauna collected by USNEL box corer includes metazoan organisms retained by a $250 \mu \mathrm{m}$ mesh. In this study, we have considered macrofauna sensu stricto (Hessler \& Jumars 1974), excluding meiobenthic taxa like nematodes, harpacticoid copepods and ostracods. On the one hand, those taxa are better sampled for quantitative purposes by using sorting methods specific to meiofauna because of their size (see above); on the other hand, they are present in relatively high numbers compared to other typical macrofaunal taxa, and they could introduce bias in macrofaunal counts. The sampling unit was the total surface of the core, i.e. $0.25 \mathrm{~m}^{2}$. On board, the supernatant water was drained off and sieved through a $250 \mu \mathrm{m}$ mesh sieve. Large specimens belonging to megafauna were removed. Then, the total bioturbated upper layer of sediment, distinguished by the difference in compactness, was removed and preserved in $3 \%$ borax- buffered formaldehyde. The bioturbated collected layer $(10,5$ and $3 \mathrm{~cm}$ respectively at Sites $E, M$ and $O)$ corresponds to the mixing layer $(10-12,3-4.5$ and $2-2.5 \mathrm{~cm}$ respectively at Sites $\mathrm{E}, \mathrm{M}$ and $\mathrm{O}$ ), as indicated in the 'General description of study sites' section. The different collection depths could suggest an underestimate of macrofauna density, when the collected layer was less thick, particularly at Site O. However, there is likely no significant bias in the density and biomass estimates; indeed, the vertical subsampling of box-core samples obtained at Site O during the RRS Discovery cruise 204 in September 1993 (J. Galéron \& G. Paterson unpubl. data) has shown that $95 \%$ of the macrofauna are present in the top 0 to $3 \mathrm{~cm}$ layer of sediment at this site. This result suggests that the sampling method we used gives a representative image of the macrofauna present in the sediment, with $95 \%$ of the community living in the bioturbated layer, corresponding to the mixing layer.

In the laboratory, all preserved samples were washed through a set of 3 nested sieves, with mesh openings of $1 \mathrm{~mm}, 500 \mu \mathrm{m}$ and $250 \mu \mathrm{m}$, and stained with Rose Bengal. Organisms were extracted from the sediment by elutriation, sorted out under a dissecting microscope, and identified to higher taxa (phylum, class or order). All specimens were counted in order to estimate the mean density per taxon. In order to obtain the mean biomass in wet (formalin) weight (WW), the specimens grouped per taxon, from 3 samples collected at each site during each cruise, were weighed on a microbalance after having been blotted with absorbent paper to remove excess formalin. The mean individual $W W$ was calculated for each taxon at each site and for each cruise. From mean individual WW and density data, we calculated biomass in WW. In order to obtain biomass data in carbon weight, we calculated conversion 
factors from WW to carbon weight using the following method. Water and ash content values for each taxon were evaluated in percentage of WW, following a synthesis by Mahaut (1990), using mainly a selected literature compilation (Table 3). These data were used to calculate the percentage of WW in ash-free dry weights (AFDW). The organic carbon weight was considered equivalent to $51.8 \%$ of AFDW; this value is the average value calculated from Salonen et al. (1976). That permitted calculation of the percentage of WW in organic carbon for each taxonomic group. Water and ash contents are given for gastropods without the shell (which represents $80 \%$ WW), while for bivalves they are given for specimens with shell. For the other taxa the whole body and skeleton were considered. This indirect method for obtaining organic carbon weights was used because material was to be kept intact for detailed taxonomic studies.

Cosson et al. (1997) estimated the macrofauna sampling efficiency and found that only 2 box cores were needed for a quantification of polychaetes and tanaids, 5 for isopods, and 6 for bivalves. To assess temporal variation in mean densities of the dominant macrofau- nal taxa within each site, $90 \%$ confidence intervals were calculated. Moreover, we tested for differences ( $t$-test) between sites and between seasons for mean densities of total macrofauna, and of the 4 dominant taxa (polychaetes, tanaids, isopods and bivalves). No analysis could be performed for biomass data because of the way of evaluating biomass, by using a mean individual weight.

Invertebrate megafauna. This category includes invertebrate metazoans larger than $2 \mathrm{~cm}$, visible to the naked eye on photographs. Fishes were not considered in this study because the device used to collect megafauna, a beam trawl of $5.5 \mathrm{~m}$ opening (Guennegan \& Martin 1985), does not effectively sample them. The invertebrates collected by trawl were first sorted on board to the level of phylum, class or order and preserved in $3 \%$ borax-buffered formaldehyde. In the laboratory, specimens larger than $2 \mathrm{~cm}$ were counted, washed with seawater, drained and weighed. WW (formalin) biomass estimates were converted into organic carbon biomass using conversion factors, as described above for macrofauna and detailed in Table 3. Megafaunal density and biomass were calculated after eval-

Table 3. Reference data from Mahaut (1990) used to calculate conversion factors from wet weights (WW) to organic carbon weights. DW: dry weight

\begin{tabular}{|c|c|c|c|c|c|}
\hline $\begin{array}{r}\text { Wate } \\
\quad[\%\end{array}$ & $\begin{array}{l}\text { r content } \\
6 W W \text { ) }\end{array}$ & $\begin{array}{l}\text { Ash content } \\
(\% \text { WW })\end{array}$ & $\begin{array}{c}\text { Ash free dry weight } \\
(\% W W)\end{array}$ & $\begin{array}{c}\text { Organic carbon weit } \\
(\% W W)\end{array}$ & Source \\
\hline Porifera & 80 & 10 & 10 & 5.2 & Vinogradov (1953) \\
\hline Hydrozoa & 85 & 1.3 & 13.7 & 7.1 & Vinogradov (1953) \\
\hline Octocorallia & 80 & 10 & 10 & 5.2 & Vinogradov (1953) \\
\hline Zoantharia & & & & 2.1 & J. Galéron (unpubl.) \\
\hline Actiniaria & 85.6 & 2.2 & 12.2 & 6.3 & J. Galéron (unpubl.) \\
\hline Scleractinia & & & & $1-10 \% \mathrm{DW}$ & Zibrowius (1985) \\
\hline Nemertea & 79.3 & 2.6 & 18.1 & 9.3 & Vinogradov (1953) \\
\hline Polychaeta & 78.1 & 4.4 & 17.5 & 9 & Vinogradov (1953) \\
\hline Sipuncula & 82 & 7.8 & 10.2 & 5.3 & Vinogradov (1953) \\
\hline Aplacophora & 85 & 2.5 & 12.5 & 6.5 & Vinogradov (1953) \\
\hline Gastropoda & 75.4 & 3 & 5 & 2.6 & Vinogradov (1953) \\
\hline Scaphopoda & 85 & 2.5 & 12.5 & 6.5 & Vinogradov (1953) \\
\hline Bivalvia & 48 & $70(\mathrm{DW})$ & 15.4 & 8 & Khripounoff (1979) \\
\hline Cephalopoda & 77 & 1.5 & 21.5 & 11.1 & Vinogradov (1953) \\
\hline Pycnogonida & 75 & 5 & 20 & 10.4 & Vinogradov (1953) \\
\hline Cirripedia & 30.4 & 64 & 5.6 & 2.9 & Vinogradov (1953) \\
\hline Cumacea & 80.3 & $27.9(\mathrm{DW})$ & 14.5 & 7.5 & Vinogradov (1953) \\
\hline Tanaidacea & 80.3 & 27.9 (DW) & 16.4 & 8.5 & Vinogradov (1953) \\
\hline Isopoda & 80.3 & 27.9 (DW) & 18.3 & 9.5 & Vinogradov (1953) \\
\hline Amphipoda & 78 & 6.3 & 15.7 & 8.1 & Vinogradov (1953) \\
\hline Decapoda Natantia & 76 & 3.6 & 20.6 & 10.6 & Vinogradov (1953) \\
\hline Decapoda Reptantia & 80.5 & 7.3 & 12.2 & 6.4 & Vinogradov (1953) \\
\hline Holothuroidea (translucent) & 96.2 & 3 & 0.8 & 0.5 & Barnes et al. $(1976)$ \\
\hline Holothuroidea (with dense flesh) & 79 & 50 (DW) & 10.4 & 5.4 & Vinogradov (1953) \\
\hline Asteroidea & 65 & 15 & 20 & 10.4 & Vinogradov (1953) \\
\hline Ophiuroidea & 63 & 25 & 12 & 6.4 & Smith \& Hamilton (1983) \\
\hline Echinoidea (regular) & 73.3 & $85.3(\mathrm{DW})$ & 3.9 & 2 & Vinogradov (1953) \\
\hline Echinoidea (irregular) & 55 & 93.1 (DW) & 1.3 & 0.7 & Vinogradov (1953) \\
\hline Tunicata & 90 & 6.5 & 3.5 & 1.7 & Vinogradov (1953) \\
\hline
\end{tabular}


uating the area sampled by the trawl with a precision of about $2 \%$ provided by acoustic navigation.

A photographic survey using a vertical camera was carried out at Site $M$ during the winter cruise (Eumeli 2), using the unmanned submersible 'Epaulard'. Xenophyophores were present in high densities at this site but were never collected by trawl, due to their extreme fragility. These protozoans, even if they can be present in high abundance, were not included in this study because they are thought to contribute relatively little to benthic community biomass (Levin \& Gooday 1992), due to the fact that a very small proportion of their test consists of living protoplasm.

The spatial changes between the 3 sites were andlysed ( $t$-test) for total mean densities by comparing the results from catches obtained in winter (Eumeli 2). We also tested for differences between Sites $E$ and $M$ for the dominant taxa (i.e. accounting for $>4 \%$ density at either site). Site $O$ was not considered because of the particularly low densities encountered at this site. The temporal changes could not be statistically analysed because we had no trawl catch at Site $E$ in autumn and at Site $O$ in spring and when we had data, in autumn and in spring, these data were provided by a single catch per site. Nevertheless, the temporal trends were assessed by comparing the mean density results for the winter cruise (Eumeli 2), with the densities obtained from the autumn (Eumeli 3) and spring (Eumeli 4) cruises. We calculated the $90 \%$ confidence intervals for the winter cruise. As the sampling unit surface varied between hauls, the standard deviations were calculated using the formula adapted by Sibuet \& Segonzac (1985) to the trawl sampling:

$$
\sigma=\sqrt{\sum\left[\frac{a_{i}}{\sum a_{i}} \times\left(\frac{x_{i}}{a_{l}}-\frac{\sum x_{i}}{\sum a_{i}}\right)^{2}\right]}
$$

where $\boldsymbol{a}_{i}$ is the area sampled by the $i$ th trawl and $x_{i}$ is the number of individuals in the $i$ th haul.

\section{RESULTS}

\section{Meiofauna}

Because meiofauna were sampled using 2 types of corers, differences between samples obtained with both methods were analysed ( $t$-test). Unlike Bett et al. (1994), who showed some difference in the reliability of USNEL box cores as compared to SMBA multiple corer samples, we found no significant difference in mean densities $(p>0.05)$ between the 2 sets of data. This result is probably due to the quality of samples, obtained under sea conditions that were particularly fair for coring in this geographical area, and also to the way of selecting and processing samples, as described in the 'Materials and methods'. So the data sets obtained from the 2 types of equipment were grouped for analysis.

The meiofauna was dominated by nematodes ( $>90 \%$ of total density) at all 3 sites (Table 4 a). Copepods were also well represented, with 5 to $6 \%$ of total density at Sites $E$ and $M$, and 2 to $4 \%$ at Site $O$. At the 3 sites, polychaetes were found regularly and accounted for more than $1 \%$ of total density. Among the minor taxa, tardigrades, kinorhynchs, molluscs, ostracods and tanaids were found, but did not occur regularly. In terms of biomass (Table $4 \mathrm{~b}$ ), nematodes were less important. They accounted for 45 to $52 \%$ of the total meiofauna and were matched by copepods (48 to $55 \%$ ).

Total meiofaunal mean densities $( \pm 1$ SD) were maximum at Site E, ranging from $414 \pm 129$ to $552 \pm 182$ ind per $5.31 \mathrm{~cm}^{2}$, and minimum at Site $O$, ranging from $51 \pm 8$ to $81 \pm 29$ ind. per $5.31 \mathrm{~cm}^{2}$ (Table $4 \mathrm{a}$ ). Total meiofaunal mean biomass presented the same trend of decrease from Site $E$ to Site $O$, with values ranging from 79 to $96 \mu \mathrm{g} \mathrm{C}$ per $10 \mathrm{~cm}^{2}$ at Site E, 43 to $65 \mu \mathrm{g} \mathrm{C}$ per $10 \mathrm{~cm}^{2}$ at Site $M$ and 6 to $11 \mu \mathrm{g} \mathrm{C}$ per $10 \mathrm{~cm}^{2}$ at Site $O$ (Table $4 \mathrm{~b}$ ). In winter (Eumeli 2), the mean densities were significantly different between the 3 sites ( $p<0.05$ for each pairwise comparison), for total meiofauna as well as for nematodes and copepods, with densities decreasing from Site $E$ to Site $M$ and to Site $O$. In autumn, mean total, nematode and copepod densities were significantly higher at Site $M$ than at Site $O(p<0.05)$; Site $E$ was not sampled. In spring (Eumeli 4), the differences between Sites $M$ and $O$ were significant $(p<0.05)$ for total, nematode and copepod mean densities. The sampling at Site $E$ in spring was not sufficient for statistical analysis. No temporal variation in mean densities was evidenced when observing results in Fig. 3. The statistical analysis confirmed these observations for Sites $\mathrm{E}$ and $\mathrm{O}$. However, at Site $\mathrm{M}$, mean densities were significantly higher $(\mathrm{p}<0.05)$ in autumn (Eumeli 3) than in winter (Eumeli 2) or in spring (Eumeli 4).

\section{Macrofauna}

The macrofauna samples contained 24 major taxa (Table 5). At Site E, the taxonomic composition of macrofauna (21 taxa) was highly similar during winter and spring cruises (20 taxa in common). At Site M, 16 taxa were regularly sampled during the 3 cruises. Sponges and bryozoans were regularly present in relatively high densities. Five taxa (actinians, echiurids, priapulids, holothuroids and ophiuroids) were present in low numbers only in samples from the winter cruise (Eumeli 2), probably reflecting the greater sampling effort during this cruise ( 16 box cores sorted). At Site O, only 8 taxa 


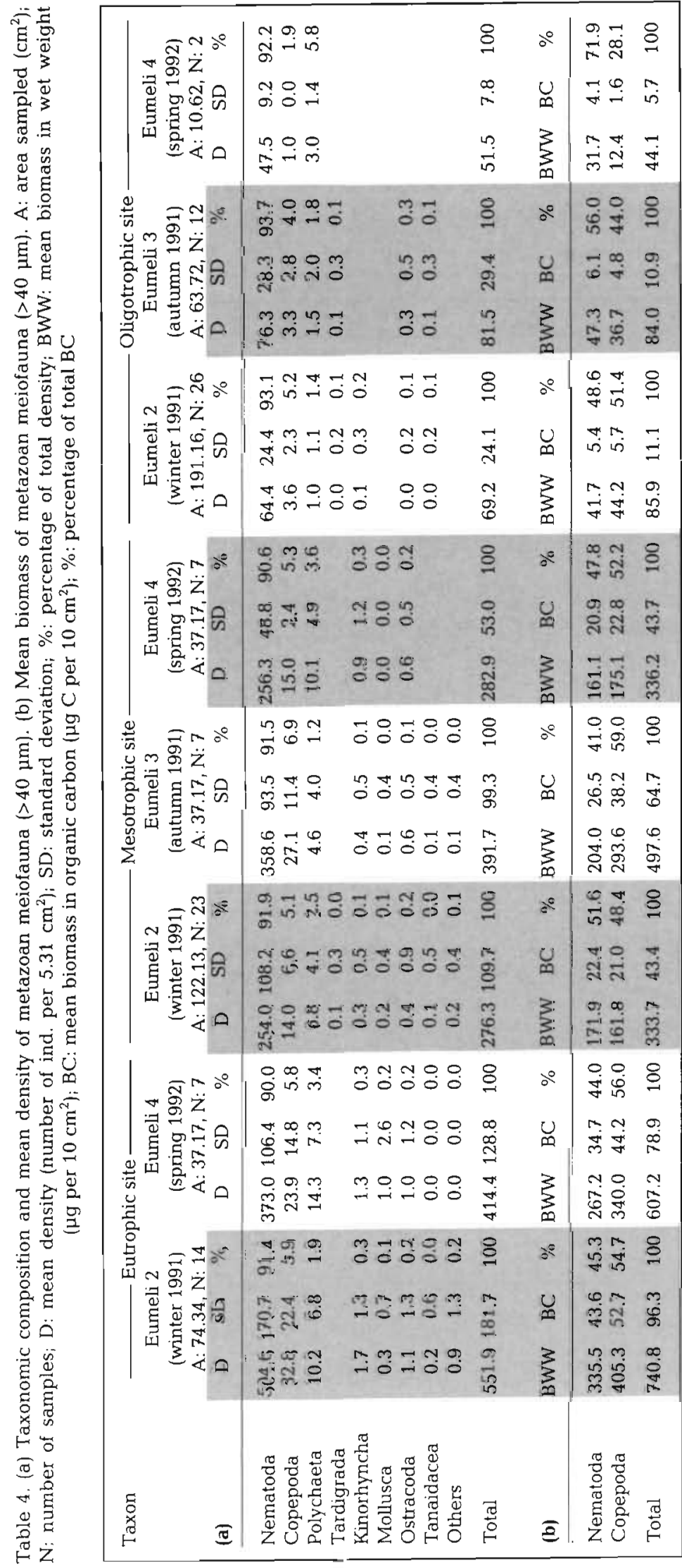

were present for every season. Six other taxa, all present in low numbers, were found in winter and/or in autumn. The most common taxa (polychaetes, tanaids, isopods and bivalves) were present at every site whatever the season and together formed 85 to $92 \%$ of macrofauna density and 80 to $95 \%$ of biomass.

Total macrofaunal mean density $( \pm 1 \mathrm{SD})$ and mean biomass ( $\pm 1 \mathrm{SD}$ ) were maximal at Site $E$, with values ranging respectively from $996 \pm 391$ to $1357 \pm 276$ ind. per $0.25 \mathrm{~m}^{2}$, and from 251 to $405 \mathrm{mg} \mathrm{C} \mathrm{m}^{-2}$, and minimal at Site $O$ (from $51 \pm 14$ to $58 \pm 14$ ind. per $0.25 \mathrm{~m}^{2}$, and from 4 to $5 \mathrm{mg} \mathrm{C} \mathrm{m}^{-2}$; Table $5 \mathrm{~b}$ ). In winter (Eumeli 2) total mean densities as well as poiychaete, tanaid, isopod and bivalve mean densities were significantly different ( $p<0.05$ for each pairwise comparison) between the 3 sites, with densities decreasing from Site $E$ to Site $M$ and to Site O. In autumn (Eumeli 3), and in spring (Eumeli 4), differences in mean densities were significant $(p<0.05)$ between the 3 sites only for total macrofauna and for polychaetes. Concerning tanaids, isopods and bivalves, differences between sites were not regularly significant, probably due to low number of samples in some data sets. Whatever the site, no temporal variation was observed (Fig. 3). The statistical analysis confirmed the observations: no significant difference $(p>0.05)$ could be detected between seasons, for mean densities of total macrofauna, polychaetes, tanaids, isopods or bivalves.

\section{Megafauna}

Invertebrate megafauna were collected using a beam trawl at the 3 sites in winter (Eumeli 2), at Sites $M$ and $O$ in autumn (Eumeli 3) and at Sites $E$ and $M$ in spring (Eumeli 4). They were observed using 'Epaulard' only at 1 site (M) during 1 season (winter). Neither of these methods is adequate to obtain a complete set of representative data on the whole benthic megafauna (Laubier \& Sibuet 1979, Rice et al. 1979, 1982. Mauviel 1982, Sibuet \& Segonzac 1985, Richardson \& Young 1987, Christiansen \& Thiel 1992, Thurston et al. 1994). Trawling is thought to underestimate the total megafaunal community (Thurston et al. 1994), though photography may yield abun- 
Eutrophic site
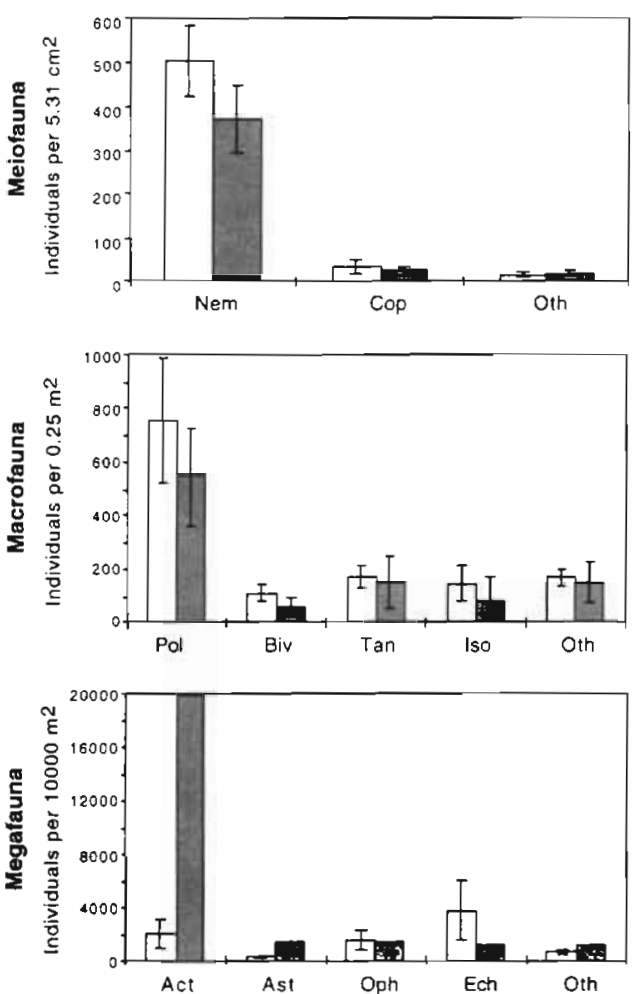

Mesotrophic site
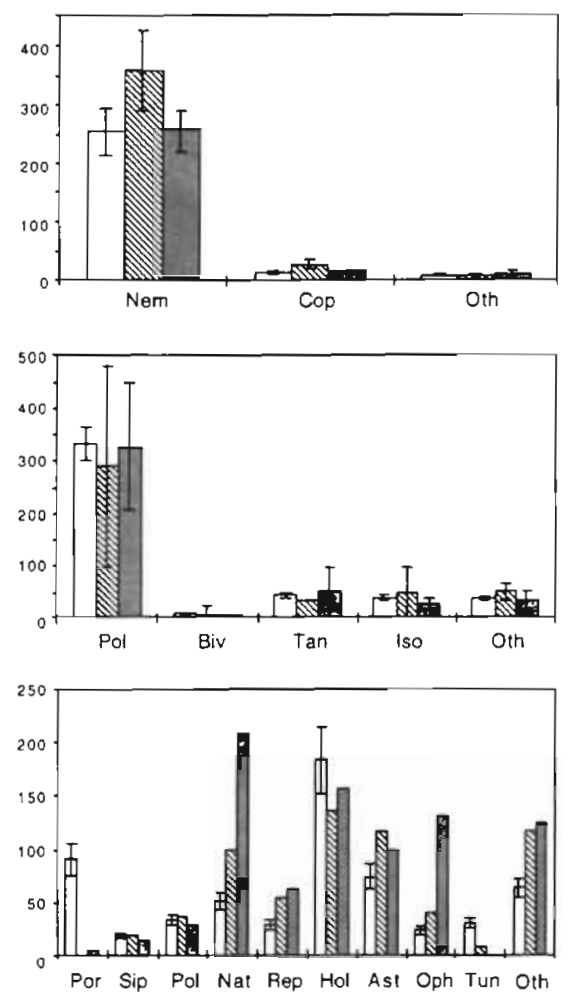

Oligotrophic site
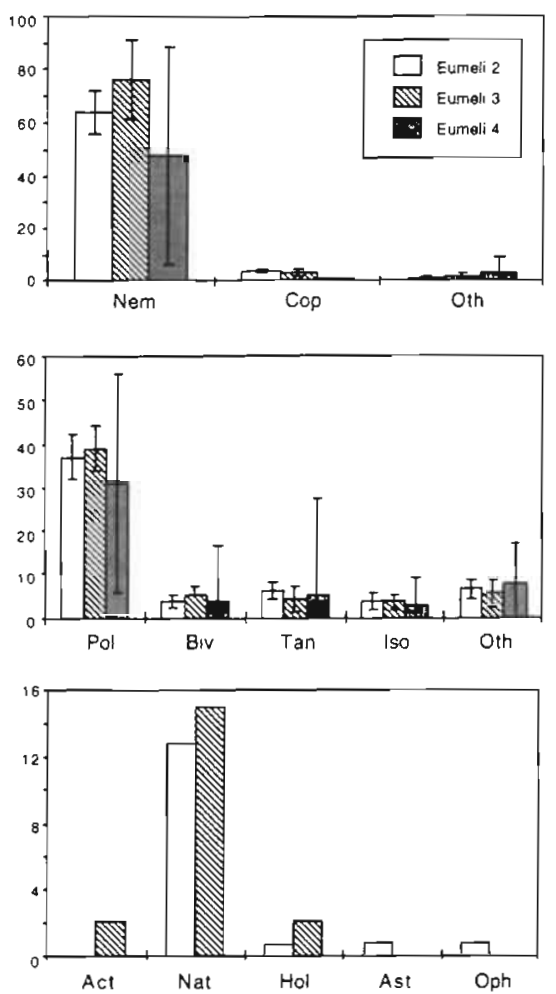

Fig. 3. Mean densities of the most common taxa of the 3 size classes of benthic organisms at the 3 Eumeli sites during cruises Eumeli 2, 3 and 4. Act: Actiniaria; Ast: Asteroidea; Biv: Bivalvia; Cop: Copepoda; Ech: Echinoidea; Hol: Holothuroidea; Iso: Isopoda; Nat: Decapoda Natantia; Nem: Nematoda; Oph: Ophiuroidea; Oth: Others; Pol: Polychaeta; Por: Porifera; Rep: Decapoda Reptantia Sip: Sipuncula; Tan: Tanaidacea; Tun: Tunicata

dance lower than values obtained by trawls (Mauviel 1982, Richardson \& Young 1987). Given that we did not conduct a photographic survey at the 3 sites, and that we obtained a sufficient trawling data set at the 3 sites in winter, we used the trawl data for a comparison between the Eumeli sites. Comparisons between seasons are mentioned, but significance cannot be assessed due to the lack of data.

The collected invertebrate megafauna comprised a total of 24 taxa (Table 6). At Site E, 21 taxa were collected during the winter cruise (Eumeli 2), while only 14 were found in spring (Eumeli 4). Unlike meiofauna and macrofauna, which were composed of the same dominant taxa whatever the site or the season, the megafauna was composed of different dominant taxa at the different sites. At Site $E$, echinoids, actinians, ophiuroids, and asteroids together accounted for $>90 \%$ of density in the winter cruise samples (Fig. 4). In terms of biomass, actinians largely dominated, while echinoderms were less important. Cephalopods represented $4 \%$ of biomass because of their relatively large size. In the spring trawl catch, actinians largely dominated the megafaunal community, accounting for $79 \%$ of density and $86 \%$ of biomass. As a consequence, the other taxa were relatively poorly represented. At Site M, 20 taxa were found, of which 12 were present during every cruise. The rare taxa were collected only when the sampled area was the largest, i.e. in winter. In terms of density, there was no strongly dominant taxon and the megafauna were distributed more equally among 8 major taxa (Fig. 4). Among echinoderms, which represented about $50 \%$ of density during every cruise, holothuroids were the most abundant, followed by asteroids and ophiuroids. In addition to echinoderms, natantian and reptantian decapods, sponges, large polychaetes and tunicates were present. In terms of biomass, the dominance of echinoderms was evident $(76 \%)$, especially holothuroids $(58 \%)$, and only 3 other taxa were represented by more than $4 \%$ of biomass: natantian and reptantian decapods and sipunculids. At Site $O$, the dominant taxon was natantian decapods ( $\sim 80 \%$ density, $\sim 95 \%$ biomass) (Fig. 4) during the winter and autumn cruises; 5 other taxa were collected irregularly.

The total megafaunal density $( \pm 1$ SD) was about 3 times higher in spring (25 239 ind. ha ${ }^{-1}$ from the single trawl catch) than in winter $\left(8326 \pm 2333\right.$ ind. ha ${ }^{-1}$ from 4 trawl catches) at Site $E$, and the total biomass 


\begin{tabular}{|c|c|c|c|c|c|c|c|c|c|c|c|c|}
\hline$\therefore$ & & $\begin{array}{l}\infty \infty \\
0 \infty \infty \\
0\end{array}$ & & $\begin{array}{l}\infty \\
\dot{0} \\
\dot{\varphi}\end{array}$ & 98 & $\therefore$ & & हं & $\vec{i}$ & & $\stackrel{\circ}{-}$ & $\stackrel{N}{9}$ \\
\hline 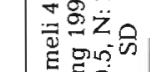 & & $\overrightarrow{b r}$ & 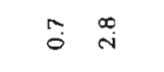 & gु & $\ddot{g}$ & u & & חึ్ & $\overrightarrow{0}$ & $\stackrel{0}{0}$ & $\because 0$ & $\overrightarrow{0}$ \\
\hline 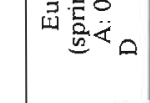 & & $\stackrel{\circ}{m}$ & $\stackrel{n}{\circ} \stackrel{0}{+}$ & is & $\stackrel{0}{i} \stackrel{0}{\dot{n}}$ & $\sum_{\mathbf{m}}^{3}$ & & $\underset{\infty}{\pi \infty}$ & $\stackrel{m}{\rightarrow}$ & $\ddot{0}$ & $\ddot{0}=$ & $\begin{array}{ll}n \\
\text { in } \\
\text { in }\end{array}$ \\
\hline 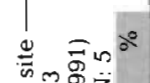 & & 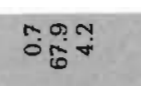 & $\overbrace{-\infty}^{2}$ & $=3$ & \pm 8 & $\therefore$ & & $\begin{array}{l}0 \\
=0 \%\end{array}$ & $\overrightarrow{\text { तु }}$ & กี่ & 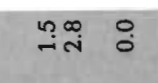 & :0 : \\
\hline 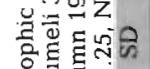 & & 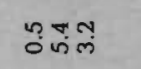 & סํำ & लिं & $\begin{array}{ll}\infty \\
0 \\
0 & \infty \\
\infty\end{array}$ & u & & ஜำำ & 뭉웅 & $\stackrel{\infty}{0}$ & ีㅜㅇㅇㅛ & $\therefore$ : \\
\hline م & & 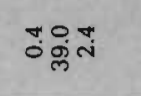 & 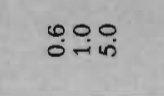 & अَّ & $\stackrel{\infty}{\infty} \underset{0}{0}$ & 咅 & & ஜू०० & $=-1$ & $\stackrel{\circ}{\varrho}$ & $=0$ & 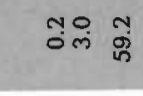 \\
\hline & ก̃ & 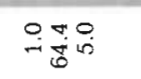 & Q⿻日禸 & דo: & $\stackrel{4}{-} \stackrel{\circ}{\circ}$ & $\therefore$ & 8 & $\tilde{S} \underset{\infty}{N} \stackrel{\infty}{\infty}$ & $\stackrel{\circ 0}{-0}$ & $\vec{i}$ & 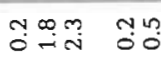 & ? : क : \\
\hline 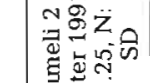 & $\stackrel{m}{8}$ & $\begin{array}{l}M \\
0 \\
0\end{array}$ & tiong & 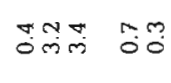 & 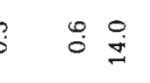 & $\stackrel{u}{.}$ & $\stackrel{\circ}{\circ}$ & $\ddot{0}$ & 웅 & $\overrightarrow{0}$ & 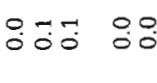 & $\stackrel{m}{\dot{q}}$ \\
\hline 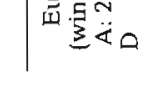 & $\overrightarrow{0}$ & $\ddot{\circ}: \vec{m}$ & 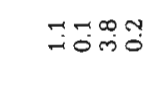 & 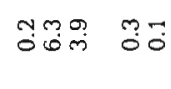 & $\overrightarrow{5} g$ is & 离 & $\ddot{0}$ & 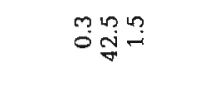 & 웅 & $\Xi$ & $\underset{\delta}{ }$ & $=\stackrel{0}{\circ}$ \\
\hline & $=$ & 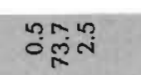 & 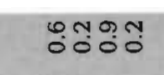 & : & $\overrightarrow{0} \stackrel{ }{-}$ & $\therefore$ & -io & $\underset{-\infty}{-\infty}: 0$ & कील & 둥웅요 & 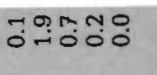 & :ํㅛ \\
\hline অ & m. & 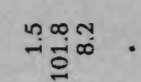 & 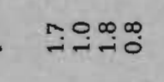 & 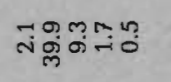 & $\stackrel{\circ}{\circ} \overrightarrow{\mathrm{B}}$ & u & mi: & 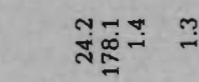 & : & उत् & 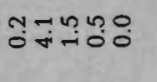 & 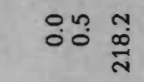 \\
\hline & 요. & 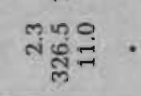 & | & 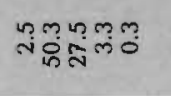 & 䑸 in & 空 & 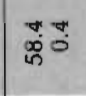 & : & मृ. & Pृ & 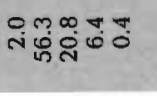 & 일 ल \\
\hline 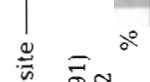 & $\stackrel{m}{i}$ & $\operatorname{lng}_{0}^{\infty} \underset{0}{0}$ & 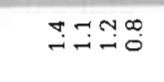 & 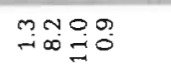 & 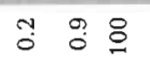 & 2 & సi: & 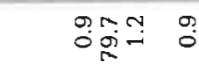 & 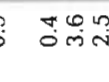 & No & $\because \underset{10}{ }$ & $\because$ \\
\hline 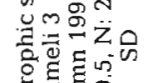 & $\stackrel{\infty}{i}$. & $\stackrel{\square}{-G}$ & 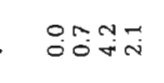 & 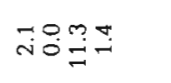 & 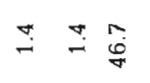 & 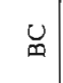 & ĩo & 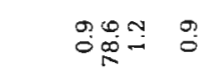 & b ت̆丶 & & 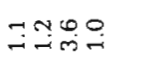 & $\ddot{0}: 000$ \\
\hline$\sum_{1}^{0}$ & @. & 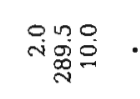 & 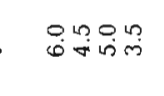 & 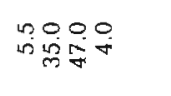 & 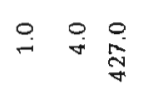 & $\sum_{m}^{3}$ & $\underset{\sigma}{\dot{\sigma}}$ & 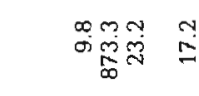 & 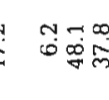 & & 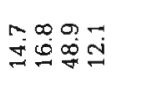 & 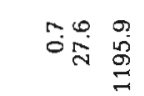 \\
\hline & $\because:$ & คู & 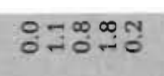 & 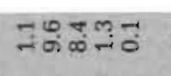 & 궁ㅇㅇ & $\therefore$ & $\stackrel{20}{-6}$ & $\because \mathscr{0}$ & 905 & $5=$ & 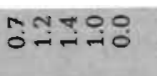 & 용표 \\
\hline 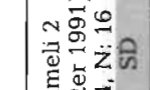 & in. & 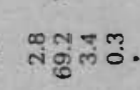 & $\rightarrow \infty$ & نి & சீํำ & u & $\exists \infty$ & : & :30- & & 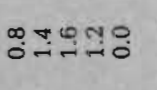 & : \\
\hline & in. & 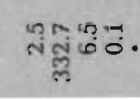 & $\lim _{-\infty}=$ & 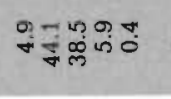 & 药 & 高 & तี่ & $\overline{0}$ - & ?ing & & 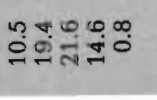 & 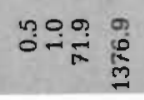 \\
\hline$\pi^{\circ}$ & & $\begin{array}{l}000 \\
0-1\end{array}$ & 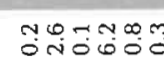 & 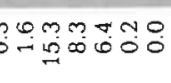 & :00: & $\therefore$ & $\stackrel{\circ}{0}$ & 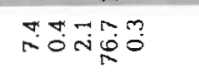 & $\stackrel{0}{0}=\ln ^{\infty} \stackrel{\infty}{0}$ & $\begin{array}{ll}x \\
9\end{array}$ & 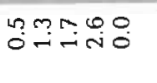 & 퍼요 \\
\hline 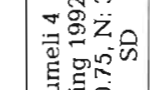 & & 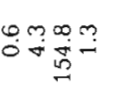 & $\vec{i} \infty-\dot{p}$ & 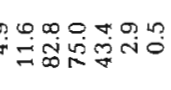 & 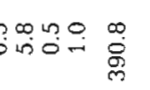 & 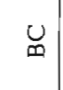 & & 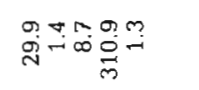 & Оु००ण & 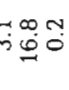 & جـ & 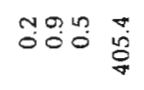 \\
\hline 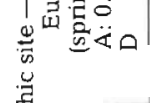 & & 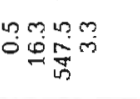 & 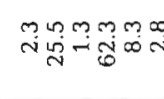 & 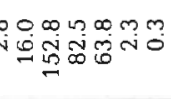 & $\begin{array}{l}\text { fiming } \\
\text { fing }\end{array}$ & $\sum_{i=1}^{3}$ & & 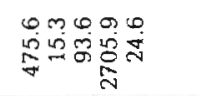 & $\dot{0}$ & $\frac{-\pi}{-\pi}$ & 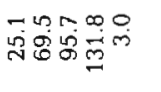 & 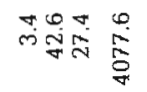 \\
\hline & & 이류. & 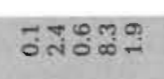 & 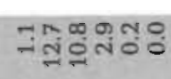 & 등용 용 & $\therefore$ & & 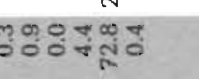 & :궘유 & $8 m$ & 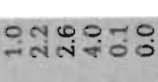 & $50:$ \\
\hline 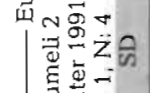 & & भुन्म & 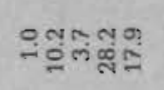 & 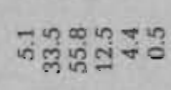 & 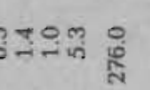 & U & & ำ & :लm- & & nimegen & 50유 \\
\hline 焉喜远 & & 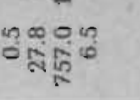 & 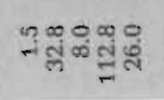 & 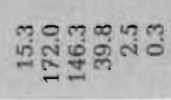 & bis & $\sum_{0,}^{3}$ & & - & 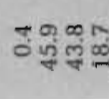 & & 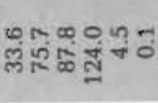 & : \\
\hline $\begin{array}{l}\text { : } \\
\text { 离 } \\
\text { r }\end{array}$ & 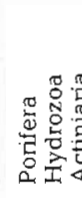 & 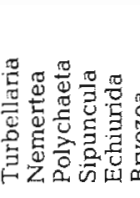 & 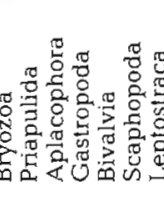 & 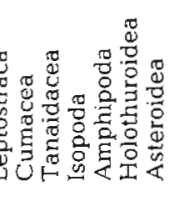 & 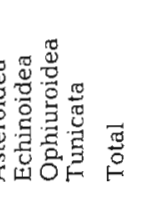 & E & 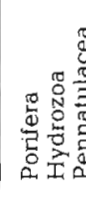 & 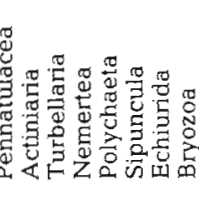 & 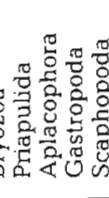 & 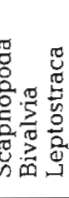 & 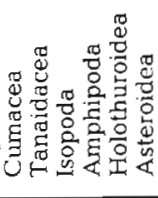 & 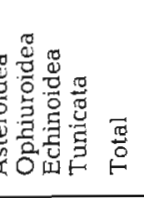 \\
\hline
\end{tabular}




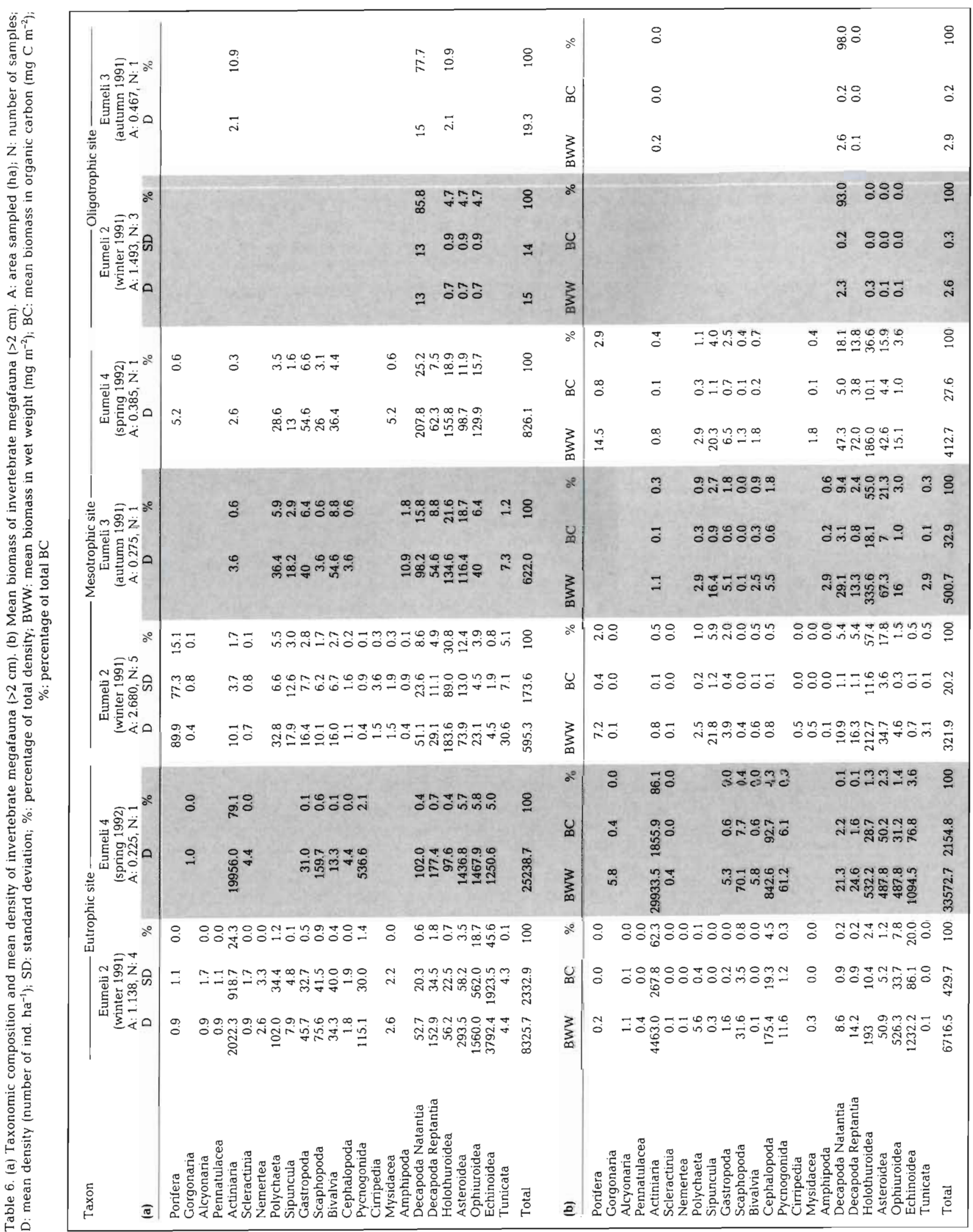




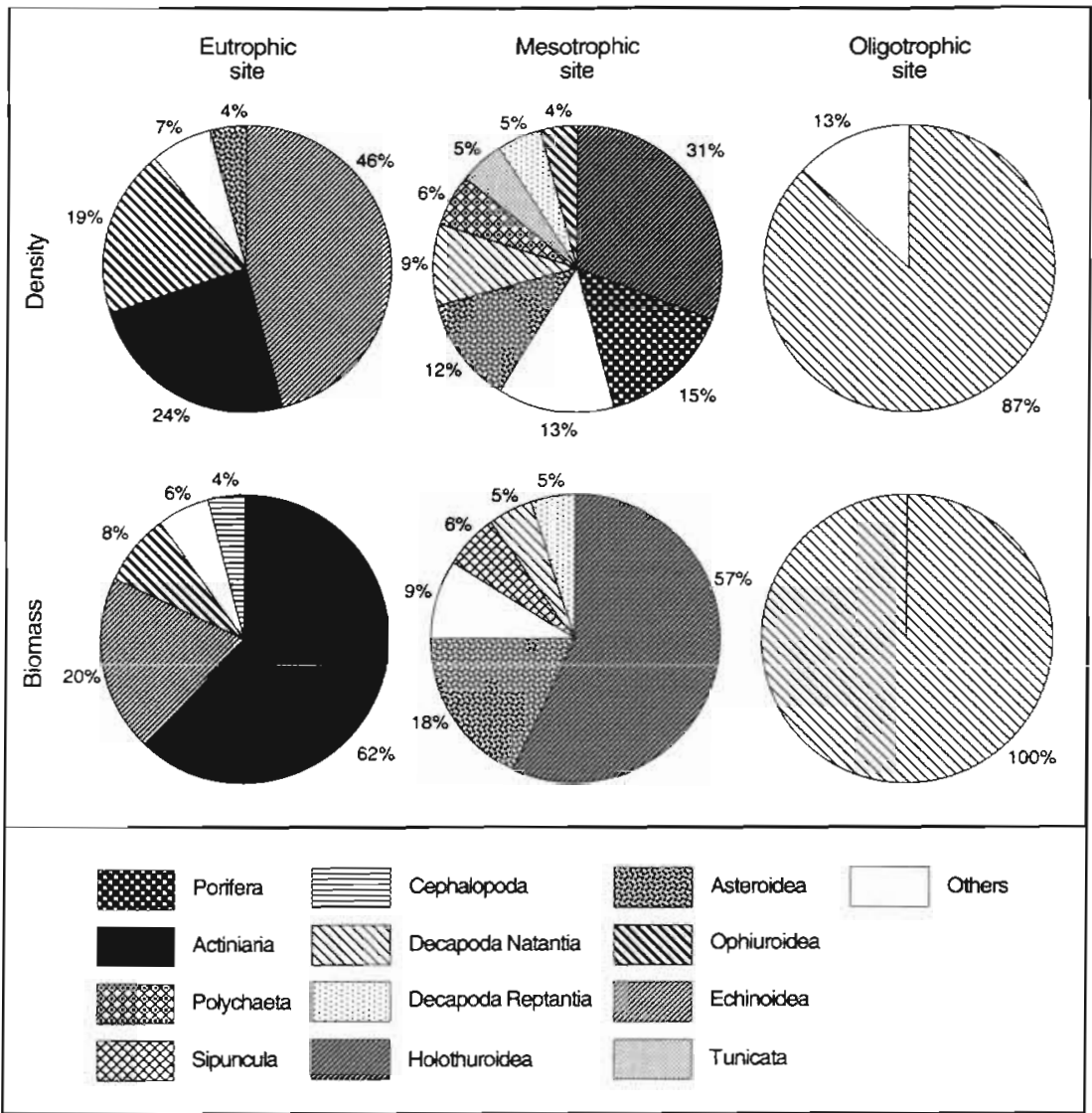

Fig. 4. Distribution of density and biomass among the dominant megafaunal taxa at the 3 Eumeli sites during the winter cruise (Eumeli 2). Total density was 8326 ind. ha ${ }^{-1}$ at Site E, 595 ind ha $^{-1}$ at Site $M$ and 15 ind. ha ${ }^{-1}$ at Site $O$. Total biomass was $4297 \mathrm{~g} \mathrm{C} \mathrm{ha}^{-1}$ at Site E, $202 \mathrm{~g} \mathrm{Cha}^{-1}$ at Site $\mathrm{M}$ and $3 \mathrm{~g} \mathrm{Cha}^{-1}$ at Site $\mathrm{O}$
5 times higher (21547 $\mathrm{g} \mathrm{C} \mathrm{ha}^{-1}$ vs $4297 \mathrm{~g} \mathrm{C} \mathrm{ha}^{-1}$ ). This was mainly due to a large number of actinians collected in the only spring trawl haul (10 times more than in winter catches) (Fig. 3). In contrast, at Site M, total megafaunal density and biomass did not exhibit large variation between seasons, with density values ranging from $595 \pm 174$ ind. ha ${ }^{-1}$ in winter, to 622 ind. ha ${ }^{-1}$ in autumn and 826 ind. ha ${ }^{-1}$ in spring. Total biomass values ranged from $202 \mathrm{~g} \mathrm{C} \mathrm{ha}^{-1}$, to $329 \mathrm{~g} \mathrm{C} \mathrm{ha}^{-1}$ and $276 \mathrm{~g} \mathrm{C} \mathrm{ha}^{-1}$, for the same periods respectively. At Site $O$, the main feature of the megafauna was its scarcity with less than 20 ind. ha ${ }^{-1}$.

Total megafaunal mean densities were significantly different ( $p<0.05$ for each pairwise comparison) at the 3 sites, decreasing from Site $\mathrm{E}$ to Site $\mathrm{M}$ and to Site $\mathrm{O}$. Considering the dominant taxa at Sites $\mathrm{E}$ and $\mathrm{M}$ (i.e. representing $>4 \%$ of total density at either site), mean densities significantly decreased $(p<0.05)$ from Site E to Site $M$ for actinians, polychaetes, reptantian decapods, asteroids and ophiuroids. For both sipunculids and natantian decapods, no difference was evident $(p>0.05)$, while for sponges and tunicates, mean densities were significantly higher at Site $M$ than at Site $E(p<0.05)$. The temporal variation within each site could not be statistically analysed because the sampling was not suffi- cient in autumn and in spring, but the temporal trends were assessed by comparing the mean density results for the winter cruise (Eumeli 2), with the densities obtained from the autumn (Eumeli 3) and spring (Eumeli 4) cruises (Fig. 3). No variation was observed, except in the case of actinians at Site E, as mentioned above.

\section{DISCUSSION}

\section{Are there temporal changes in abyssal benthic communities at low latitudes?}

The Eumeli-JGOFS programme was carried out in the tropical Atlantic, off Cap Blanc. This area is known to be under the influence of a strong seasonal coastal upwelling, leading to a seasonal variation in primary production at Site $E$, with a maximum in June-July (Morel 1996). At Site M, weaker variations occurred between April and October, while at Site $O$ the primary production was rather constant. Did these variations have an effect on the structure of benthic communities?

The taxonomic structure of each size class was rather constant at any one site; the dominant taxa were the 
same over time within a single site (Tables 4, $5 \& 6$ ), and the distribution of density and biomass among these taxa was similar during the different seasons, except for megafauna at Site E (Fig. 4). At this site, the density of actinians in the single trawl catch from the spring cruise $(\sim 20000$ ind. $\mathrm{ha}^{-1}$ ) was 10 times greater than the mean value for the 4 winter catches ( -2000 ind. ha $\left.{ }^{-1}\right)$, which in turn made the actinians the largely dominant taxon, in terms of density (79\%) and biomass $(86 \%)$. The actinians were mainly composed of Actinoscyphia aurelia (K. Riemann-Zurneck pers. comm.), a species for which Aldred et al. (1979) reported unusually high population densities (1000 to 55000 ind. $h a^{-1}$ ) in the same area around $2000 \mathrm{~m}$ depth. Aldred et al. (1979) suggested that the biological characteristics, especially the feeding habit, of $A$. aurelia are ideally suited to the environmental conditions in this area. In our study, the specific explosion of the $A$. aurelia community in the spring catch could suggest a possible effect of the primary production seasonality at Site $E$, but the insufficient sampling in spring does not permit us to conclude that the change observed between the 2 seasons is significant. This difference in actinian densities between the catches could more likely be linked to the patchy distribution of megafauna (Aldred et al. 1979).

In terms of density, no significant temporal change was evidenced for the 3 benthic size classes at the 3 sites, except at Site $M$, where we found higher macrofaunal densities in autumn samples than in samples obtained in winter or in spring.

\section{Variations in structure and biomass of the benthic communities in 3 different environmental settings}

Because there was no evidence for temporal change for most of the components of the benthic communities, and because the most intensive sampling was during the winter cruise (Eumeli 2), we used winter results for the comparison of the 3 sites. As expected in a region under the influence of strong upwelling, benthic standing stocks at Site $\mathrm{E}$ were particularly high, which corroborates results obtained in the same region by Nichols \& Rowe (1977), Thiel $(1978,1982)$ and Aldred et al. (1979). For each size class, density and biomass decreased with increasing depth, resulting in particularly low values at Site O (Table 7). These results match values obtained at the same site during a Discovery cruise in September 1993 (Vanreusel et al. 1995, Thurston et al. 1998). In Table 7 , the results are presented with the same unit sur- face for the 3 size classes (i.e. $\mathrm{m}^{2}$ ). The rate of decrease in meiofauna from the shallowest $(E, 1700 \mathrm{~m}$ ) to the deepest site $(O, 4500 \mathrm{~m})$ was the same in terms of density and biomass, both values being 8 times lower at the deepest site. However, the difference between Sites $M$ and $O$ was twice that between Sites E and M. For macrofauna, the $E / O$ density ratio was 24 , with a greater decrease between Sites $M$ and $O$, as well. The $E / O$ biomass ratio was 54 with the greatest biomass decrease between Sites $M$ and $O$. The same trend was true for megafauna with even higher ratios: 546 between the extreme sites (E/O) in density and 1638 in biomass, with ratios about 4 times higher between Sites $M$ and $O$. These results show that the rate of decrease in both density and biomass varied according to the size group, the large organisms presenting the greatest changes, as previously suggested by Sibuet \& Segonzac (1985). Moreover, mean biomass shows a greater proportional drop than density for macrofauna and especially for megafauna, reflecting the trend of a depth-related variation in average body size of organisms, as reported for most faunal components across the meio-megafauna size range (Thiel 1975, Gage 1978, Sibuet et al. 1984, 1989, Lampitt et al. 1986).

Looking at the relationships between the 3 size groups, density ratios varied relatively little between sites: the smaller the size, the higher the density. At the 3 sites, total meiofaunal densities were 2 orders of magnitude higher than macrofaunal densities. Megafaunal densities were 4 or 5 orders of magnitude lower than macrofaunal densities (Table 7 a). Unlike density, the biomass ratios did not exhibit the same trend of decrease from the smallest size class to the largest one at the 3 sites. Indeed, at Site $E$, megafaunal biomass was respectively 2 and 5 times higher than values for macrofaunal and meiofaunal biomass. At Site $M$, the macrofaunal biomass was respectively 3 and 6 times higher than those for meiofauna and megafauna. At Site $O$, meiofauna exhibited the highest biomass, respectively 3 and 43 times higher than for macrofauna and mega- 
fauna (Table $7 \mathrm{~b}$ ). As a result, the structure of benthic metazoan fauna varied between the 3 sites (Fig. 5), megafauna dominating at the shallowest site (E) with $56 \%$ of metazoan biomass, macrofauna at the intermediate site (M) with $65 \%$ and meiofauna at the abyssal site (O) with $71 \%$ respectively. So, we have stressed that under contrasting environmental conditions the benthic community structure varies; at each typical situation a different size class dominates the benthic biomass.

\section{Influence of abiotic and biotic factors on the structure of benthic communities}

The Eumeli programme has been one of very few to address the benthic communities simultaneously with the environmental conditions. This comprehensive data set allowed examination of different factors able to influence the benthic communities. The 3 Eumeli sites were located at depths varying from $\sim 2000$ to $\sim 4500 \mathrm{~m}$, but depth is unlikely to be the only factor governing the observed gradient in benthic standing stocks; it is more likely that a suite of factors related to water depth play a role.

One of the most important factors varying with depth is the supply of organic matter to the sea floor. In our study areas, the food that sustains the benthos consists of the POC flux that reaches the sea floor, originating mainly from the surface primary production. The primary production and POC flux values decreased from Site $\mathrm{E}$ to Site $\mathrm{O}$ (Table 1). The POC flux ratio between the extreme sites was about 3 times higher than the primary production ratio ( $\sim 15$ vs $\sim 4$ ). In addition, both factors presented a higher decrease between Sites $M$ and $O$ than between Sites $E$ and $M$. The same trend of decrease was observed for the overall benthic metazoan biomass that varied from $777 \mathrm{mg} \mathrm{C} \mathrm{m}^{-2}$ at Site $\mathrm{E}$, to $179 \mathrm{mg} \mathrm{C} \mathrm{m}^{-2}$ at Site $\mathrm{M}$ and $15.8 \mathrm{mg} \mathrm{C} \mathrm{m}^{-2}$ at Site $\mathrm{O}$, i.e. a biomass ratio -49 between the extreme sites, with a higher ratio between Sites $M$ and $O$ than between Sites $E$ and $M(\sim 11$ vs $\sim 4)$. This clear positive relationship between benthic metazoan biomass and food input to the sea floor suggests that food limitation is the major factor controlling benthic biomass. The relation between food availability and benthic biomass has already been demonstrated in previous studies, often for a single size class, or for global benthic communities by large synthesis of data originating from various studies in different oceanic regions (Rowe 1971, Hessler \& Jumars 1974, Thiel 1979, Carey 1981, Pfannkuche et al. 1983, Lampitt et al. 1986, Sibuet 1987. Sibuet et al. 1989, Thurston et al. 1994, Vincx et al. 1994). Our comprehensive study across the 3 major

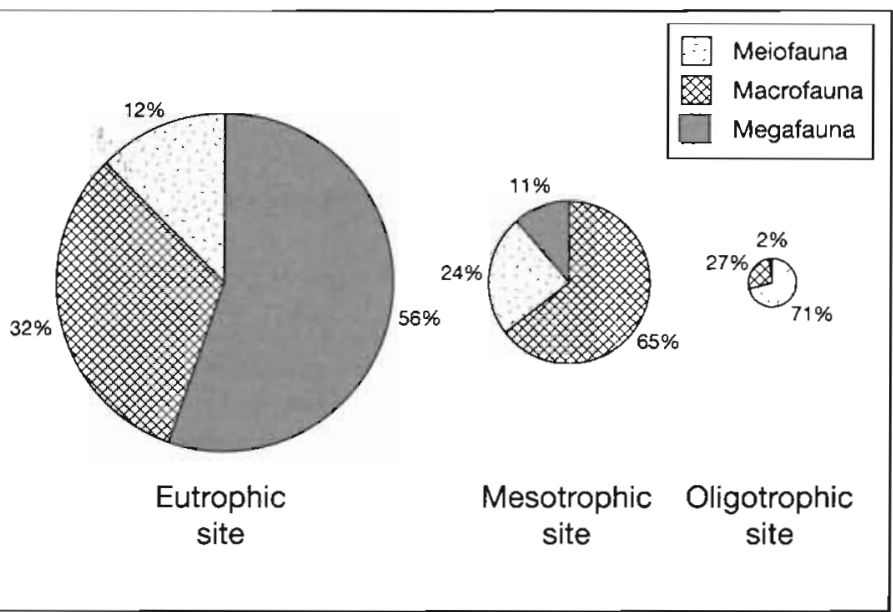

ig. 5. Biomass distribution among the 3 size classes of benthic communities at the 3 Eumeli sites. Total metazoan biomass was $777 \mathrm{mg} \mathrm{C} \mathrm{m}^{-2}$ at Site $\mathrm{E}, 179 \mathrm{mg} \mathrm{C} \mathrm{m}^{-2}$ at Site $\mathrm{M}$ and $15.8 \mathrm{mg} \mathrm{C} \mathrm{m}^{-2}$ at Site $\mathrm{O}$

benthic metazoan size classes within a single geographical area permitted us to clearly demonstrate that each size class responds differently to the variation in food input. The biomass ratios between the extreme sites were different according to the size class: 8 for meiofauna, 58 for macrofauna and 1430 for megafauna (Table $7 \mathrm{~b}$ ). In addition, we noticed that the biomass of the dominant size class, expressed as a proportion of the overall metazoan biomass, increased when the food resources decreased (Fig. 5). Thus, at Site E, the high food supply allows in turn the development of high benthic biomass, dominated by megafauna $(56 \%)$, but also largely composed of both other size classes. At this site, the dominance of megafauna may also be linked to the periodicity in the food supply induced by the seasonality of coastal upwelling. Indeed, large animals, whose life may span the full year or more, are probably better able to cope than short-lived, small organisms such as meiofauna. At Site $M$, characterized by intermediate food supply conditions, macrofauna dominated and accounted for $64 \%$ of metazoan biomass. At this intermediate site, the trophic conditions did not allow optimal development of all the size groups; the large organisms are the first to suffer from the decrease in food availability. At Site $O$, where trophic conditions were extremely poor, only small organisms thrive, as their needs in food are lower than those of large organisms. As a result, meiofauna largely dominated total metazoan biomass $(71 \%)$ and megafauna were very scarce $(2 \%)$, highlighting that large organisms were clearly the most sensitive to the decrease in food supply.

However, exceptions to the trend of decreasing biomass with decreasing food supply were noticed with a few taxa present in equivalent or higher quantities 
at Site $M$ than at Site $E$. Thus, among macrofauna, sponges and bryozoans were absent at Site $E$ and present at $M$. In addition, some megafaunal taxa were as abundant at Site $M$ as at Site $E$ (sipunculids and reptantian decapods), while others were more abundant at Site $M$ than at Site $E$ (sponges, tunicates and holothuroids), despite the lower food input. So, within a single size group, some taxonomic entities respond differently to environmental settings, suggesting that food availability is not the only factor governing the structure of the benthic fauna.

A number of environmental factors that could affect the benthic community structure were investigated in the Eumeli programme (Table 1). Physiologically important factors, such as temperature, salinity and pressure, were shown by Carney et al. (1983) to have a minor effect on zonation of benthic fauna beneath $1000 \mathrm{~m}$ depth, because their greatest changes happen within the top $1000 \mathrm{~m}$ in the ocean. Very few studies have addressed the influence on benthic fauna of inorganic components in the benthic boundary layer. Yet we know that the undersaturation in calcium carbonate of the bottom water and of the top layer of sediment could be a limiting factor for some components of the benthic fauna at abyssal depths. Particulate inorganic carbon fluxes in the bottom water and in the top layer of sediment measured by A. Khripounoff (unpubl. data) at Site $O$ were equivalent, showing that there was no dissolution of $\mathrm{CaCO}_{3}$. Therefore this factor had no effect on the structure of benthic fauna at our study areas.

One of the most variable environmental factors among the Eumeli sites was the near-bottom current velocity (Table 1). Currents may affect the benthic communities in many ways. Rhoads \& Young (1970) have stressed that current speed values exceeding $10 \mathrm{~cm} \mathrm{~s}^{-1}$ induce sediment resuspension. Cosson-Sarradin et al. (1998) showed that bottom current velocities exceeding $10 \mathrm{~cm} \mathrm{~s}^{-1}$ were common at Site $E_{\text {, while }}$ they occurred rarely at Site $M$ and they were absent at Site $O$. Therefore, the current conditions encountered at Site E were likely to favour a high concentration of suspended organic particles, forming a good food source for suspension feeders. Indeed, at this site, the benthic metazoan biomass was dominated by Actinoscyphia aurelia, which feeds on detrital material transported by near bottom currents (Aldred et al. 1979). As the bottom currents induced sediment resuspension, they also probably induced a relative instability of the surface layer of sediment, preventing the settling of small epifaunal organisms. Indeed, we noticed the absence at this site of small suspension feeders such as hydrozoans, sponges, bryozoans and tunicates.

The disturbance of the sediment was probably also due to the presence in large quantities of 2 echinoids, Pourtalesia aff. alcocki (B. David pers. comm.), which is a surface sediment detritus feeder, and which could participate in the surface sediment bioturbation, and Brissopsis atlantica mediterranea, which is a sediment dweller and probably participates in deeper bioturbation. This suggestion is confirmed by the high bioturbation rate and the relatively large mixed layer thickness at Site $E$ (Table 1). In contrast, at Site $M$, where bottom current velocities exceeding $10 \mathrm{~cm} \mathrm{~s}^{-1}$ occurred rarely, the small suspension feeders (hydrozoans, sponges, bryozoans and tunicates) were present in significant quantities. Another important megafaunal taxonomic group, the holothuroids, showed unexpected higher densities at Site $M$ than at Site E. At Site $M$, this group was mainly dominated by 2 species of Elpidiidae (Ellipinion delagei and E. papillosum) and 1 species of Synallactidae (Mesothuria verrilli) (M. Sibuet unpubl. data). These animals, which are surface dwellers feeding on detritus by skimming the surface of sediment, are nearly absent at Site E. At this site, a large part of the edible organic particles could probably not settle on the bottom, because of the current conditions on the one hand, and because $A$. aurelia first obtained this food supply. So the Elpidiidae and the Synallactidae could probably not find suitable feeding conditions at Site E, despite the high food availability. On the other hand, the holothuroids are known to be well suited for subsisting on nutrient-poor sediments, as they are able to ingest large amounts of sediment to find the food they need to thrive (Hansen 1975). Therefore, if the trophic conditions are the major factor controlling the benthic standing stocks at the level of the global communities, as well as at the level of each size group, a suite of other abiotic and biotic factors may play an important role in structuring the benthic communities when looking at a detailed taxonomic level.

\section{CONCLUSION}

The standing stocks and the structure of the benthic metazoan communities in 3 contrasting settings in the tropical Northeast Atlantic reflect the environmental differences. The decreasing trend of metazoan benthic biomass with decreasing food supply shows the dependence of benthic biomass on food availability. Looking simultaneously but separately at the 3 major benthic size classes demonstrates that each one responds differently to the decrease in food supply, with evidence that large organisms are clearly the most sensitive. This difference leads to a modification in the quantitative structure of the benthic communities. Nevertheless, trophic differences were not the only factor affecting the structure of benthic communities; they were overlaid by prevailing physical conditions and biological differences. 
Acknowledgements. We would like to thank the crews, captains and science parties of the NO 'l'Atalante' cruises we participated in. We are also indebted to our IFREMER colleagues, in particular A. Khripounoff, A. Vangriesheim, N. Cosson-Sarradin and T. Comtet, for discussions on environmental and biological subjects, and G. Barbier for fruitful advice on statistical analysis. We are also grateful to N. Merrett for improving the English, to L. Levin as Contributing Editor of MEPS, and to the anonymous reviewers, for their comments that helped to improve this work. This study was carried out within the framework of the Eumeli project, as part of the France-JGOFS programme and the IFREMER deep-sea ecology programme. The work was supported in part by the European Community Marine Science and Technology (MAST) Programme under MAS2-CT920033.

\section{LITERATURE CITED}

Aldred RG, Riemann-Zürneck K, Thiel H, Rice AL (1979) Ecological observations on the deep-sea anemone Actinoscyphia aurelia. Oceanol Acta 2:389-395

Auffret GA, Geistdoerfer P, Gaillard JF, Reyss JL, Rabouille C, Voisset M, Coutelle A, Müller C, Kerbrat R, Monti S, Ondreas H, Mauviel A (1992) Caractérisation sédimentologique et biologique préliminaire des sites du projet EUMELI. C R Acad Sci Paris, Sér Il 314:187-194

Barnes AT, Quetin LB, Childress JJ (1976) Deep-sea macroplanktonic sea cucumbers: suspended sediment feeders captured from deep submergence vehicle. Science 194 $1083-1085$

Barnett PRO, Watson J, Connelly D (1984) A multiple corer for taking virtually undisturbed samples from shelf, bathyal and abyssal sediments. Oceanol Acta 7:399-408

Bett BJ, Vanreusel A, Vincx $M$, Soltwedel $T$, Pfannkuche $O$, Lambshead PJD, Gooday A.J, Ferrero T, Dinet A (1994) Sampler bias in the quantitative study of deep-sea meiobenthos. Mar Ecol Prog Ser 104:197-203

Carey AG Jr (1981) A comparison of benthic infaunal abundance on two abyssal plains in the northeast Pacific Ocean. Deep-Sea Res 28A:467-479

Carney RS, Haedrich RL, Rowe GT (1983) Zonation of fauna in the deep sea. In: Rowe GT (ed) Deep-sea biology. Wiley Interscience, New York, p 371-398

Christiansen B, Thiel H (1992) Deep-Sea epibenthic megafauna of the Northeast Atlantic: abundance and biomass at three mid-oceanic locations estimated from photographic transects. In: Rowe GT, Pariente V (eds) Deep-sea food chains and the global carbon cycle. Kluwer Academic, Dordrecht, p 125-137

Cosson N (1996) Structure et diversité des peuplements benthiques profonds en réponse à des situations trophiques contrastées dans l'océan Atlantique nord-est tropical et tempéré. Thèse de Doctorat (Océanologie Biologique), Université de Bretagne Occidentale, Brest

Cosson N, Sibuet M, Galéron J (1997) Community structure and spatial heterogeneity of the deep-sea macrofauna at three contrasting stations in the tropical northeast Atlantic. Deep-Sea Res I 44:247-269

Cosson-Sarradin N, Sibuet M, Paterson GLJ, Vangriesheim A. (1998) Polychaete diversity at tropical Atlantic deep-sea sites: environmental effects. Mar Ecol Prog Ser 165:173-185

de Jonge VN, Bouwman LA (1977) A simple density separation technique for quantitative isolation of meiobenthos using the colloidal silica Ludox-TM. Mar Biol 42:143-148

Gage JD (1978) Animals in deep sea sediments. Proc R Soc Edinb 76B: 77-93
Gage JD, Tyler PA (1982) Depth-related gradients in size structure and the bathymetric zonation of deep-sea brittle stars. Mar Biol 71:299-308

Guennegan Y, Martin V (1985) Techniques de prélèvement. In: Laubier L, Monniot C (eds) Peuplements profonds du Golfe de Gascogne. IFREMER, Paris, p 571-602

Hansen B (1975) Systematics and biology of the deep-sea holothurians. Part I: Elasipoda. In: Wolff T (ed) Galathea report. Scandinavian Science Press Ltd, Copenhagen

Hessler RR, Jumars PA (1974) Abyssal community analysis from replicate box cores in the central North Pacific. Deep-Sea Res 21:185-209

Jensen $P$ (1984) Measuring carbon content in nematodes. Helgol Meeresunters 38:83-86

Jorissen FJ, Wittling I, Peypouquet JP, Rabouille C, Relexans JC (1998) Live benthic foraminiferal faunas off Cape Blanc, NW-Africa: community structure and microhabitats. DeepSea Res I 45:2157-2188

Khripounoff A (1979) Relations trophiques dans l'écosystème benthique abyssal Atlantique: descriptions et bilan energétique. Thèse de Doctorat 3ème cycle (OcéanographieBiologie), Université Pierre et Marie Curie, Paris

Khripounoff A, Vangriesheim A, Crassous P (1998) Vertical and temporal variations of particle fluxes in the deep tropical Atlantic. Deep-Sea Res 45:193-216

Lampitt RS, Billet DSM, Rice AL (1986) Biomass of the invertebrate megabenthos from 500 to $4100 \mathrm{~m}$ in the Northeast Atlantic Ocean. Mar Biol 93:69-81

Laubier L, Sibuet M (1979) Ecology of the benthic communities of the North East Atlantic. Ambio Spec Rep 6:37-42

Legeleux F (1994) Relations entre particules marines et message sédimentaire: flux de matière dans la colonne d'eau et transformations à l'interface eau-sédiment dans l'Océan Atlantique tropical du Nord-Est. Thèse de Doctorat (Océanographie), Université Paris 6

Legeleux F, Reyss JL, Schmidt S (1994) Particle mixing rates in sediments of the northeast tropical Atlantic: evidence from ${ }^{210} \mathrm{~Pb}_{\mathrm{xs}}{ }^{137} \mathrm{Cs}_{1}{ }^{228} \mathrm{Th}_{\mathrm{xs}}$ and ${ }^{234} \mathrm{Th}_{\mathrm{xs}}$ downcore distributions. Earth Planet Sci Lett 128:545-562

Levin LA, Gooday AJ (1992) Possible roles for xenophyophores in deep-sea carbon cycling. In: Rowe GT, Pariente $V$ (eds) Deep-sea food chains and the global carbon cycling. Kluwer Academic, Dordrecht, p 93-104

Mahaut ML (1990) Modélisation à l'état stable du cycle du carbone dans le réseau trophique profond de la terrasse de Meriadzek (Golfe de Gascogne). Thèse de Doctorat (Océanographie), Université Paris VI

Mauviel A (1982) La bioturbation actuelle dans le milieu abyssal de l'Océan Atlantique Nord. Thèse de Doctorat 3ème cycle (Géologie, Océanologie et Géodynamique), Université de Bretagne Occidentale, Brest

Morel A (1996) An ocean flux study in eutrophic, mesotrophic and oligotrophic situations: the EUMELI program. DeepSea Res I: $1185-1190$

Morel A, Antoine D, Babin M, Dandonneau Y (1996) Measured and modeled primary production in the northeast Atlantic (EUMELI-JGOFS program): the impact of natural variations in photosynthetic parameters on model predictive skill. Deep-Sea Res I: 1273-1304

Nichols J, Rowe GT (1977) Infaunal macrobenthos off Cap Blanc, Spanish Sahara. J Mar Res 35:525-536

Pfannkuche $O$ (1985) The deep-sea meiofauna of the Porcupine Seabight and abyssal plain (NE Atlantic): population structure, distribution, standing stocks. Oceanol Acta 8: $343-354$

Pfannkuche $O$ (1992) Organic carbon flux trough the benthic community in the temperate abyssal northeast Atlantic 
In: Rowe GT, Pariente V (eds) Deep-sea food chains and the global carbon cycle. Kluwer Academic, Dordrecht, p $183-198$

Pfannkuche O, Theeg $R$, Thiel $H$ (1983) Benthos activity, abundance and biomass under an area of low upwelling of Morocco, Northwest Africa. Meteor Forsch Ergeb 83:85-96

Polloni P, Haedrich R, Rowe GT, Clifford CH (1979) The sizedepth relationship in deep ocean animals. Int Rev Ges Hydrobiol 64:39-46

Rabouille $C$, Gaillard JF, Sibuet $M$, Beaucaire $C$, Bonté $P$, Crassous P, Jahnke R, Khripounoff A, Legeleux F, Laureillard J, Méjanelle L, Pierre C, Relexans JC, Reyss JL (1993) Sediment geochemistry in the three Eumeli sites in the Tropical North-East Atlantic: general presentation and first results. Ann Inst Océanogr 69:36-42

Relexans JC, Deming J, Dinet A, Gaillard JF, Sibuet M (1996) Sedimentary organic matter and micro-meiobenthos with relation to trophic conditions in the tropical northeast Atlantic. Deep-Sea Res I 43:1343-1368

Rex MA, Etter RJ (1998) Bathymetric patterns of body size: implications for deep-sea biodiversity. Deep-Sea Res II 45: $103-127$

Rhoads DC, Young DK (1970) The influence of deposit-feeding organisms on sediment stability and community trophic structure. J Mar Res 28:150-177

Rice AL, Aldred RG, Billett DSM, Thurston MH (1979) The combined use of an epibenthic sledge and a deep-sea camera to give quantitative relevance to macro-benthos samples. Ambio Spec Rep 6:135-143

Rice AL, Aldred RG, Darlington E, Wild RA (1982) The quantitative estimation of the deep-sea megabenthos; a new approach to an old problem. Oceanol Acta 5:63-72

Richardson MD, Young DK (1987) Abyssal benthos of the Venezuela Basin, Caribbean Sea: standing stock considerations. Deep-Sea Res 34:145-164

Romero-Wetzel MB, Gerlach SA (1991) Abundance, biomass, size-distribution and bioturbation potential of deep-sea macrozoobenthos on the Voring Plateau (1200-1500 m. Norwegian Sea). Meeresforschung 33:247-265

Rowe GT (1971) Benthic biomass and surface productivity. In: Costlow JD (ed) Fertility of the sea. Gordon and Breach, New York, p 441-454

Rowe GT, Staresinic N (1979) Sources of organic matter to the deep-sea benthos. Ambio Spec Rep 6:19-23

Salonen K, Sarvala J, Hakala I, Viljanen ML (1976) The relation of energy and organic carbon in aquatic invertebrates. Limnol Oceanogr 21:724-730

Schwinghamer $P$ (1981) Characteristic size distributions of integral benthos. Can J Fish Aquat Sci 38:1255-1263

Sibuet $M$ (1987) Structure des peuplements benthiques en relation avec les conditions trophiques en milieu abyssal. Thèse de Doctorat d'Etat es Sciences Naturelles, Université Pierre et Marie Curie, Paris

Sibuet M, Segonzac M (1985) Abondance et répartition de l'épifaune mégabenthique. In: Laubier L, Monniot C (eds) Peuplements profonds du Golfe de Gascogne. IFREMER, Paris, p 143-156

Sibuet $M$, Monniot $C$, Desbruyères $D$, Dinet $A$, Khripounoff $A$, Rowe G, Segonzac M (1984) Peuplements benthiques et

Editorial responsibility: Lisa Levin (Contributing Editor), La Jolla, California, USA caractéristiques trophiques du milieu dans la plaine abyssale de Demerara. Oceanol Acta 17:345-358

Sibuet M, Lambert CE, Chesselet R, Laubier L (1989) Density of the major size groups of benthic fauna and trophic input in deep basins of the Atlantic Ocean. J Mar Res 47: 851-867

Sibuet $M$, Albert $P$, Charmasson S, Deming J, Dinet A, Galeron J, Guidi-Guilvard L, Mahaut ML (1993) The benthic ecosystem in the three Eumeli sites in the Northeast Tropical Atlantic: general perspectives and initial results on biological abundance and activities. Ann Inst Océanogr 69:21-33

Smith CR, Hamilton SC (1983) Epibenthic megafauna of a bathyal basin off southern California: patterns of abundance, biomass, and dispersion. Deep-Sea Res 30:907-928

Suess E (1980) Particulate organic carbon flux in the oceanssurface productivity and oxygen utilization. Nature 288: $260-263$

Thiel $H(1975)$ The size structure of the deep-sea benthos. Int Rev Ges Hydrobiol 60:575-606

Thiel $\mathrm{H}$ (1978) Benthos in the upwelling regions. In: Boje R, Tomczak $M$ (eds) Upwelling ecosystems. Springer-Verlag, Berlin, p 124-138

Thiel H (1979) Structural aspects of the deep-sea benthos. Ambio Spec Rep 6:25-31

Thiel H (1982) Zoobenthos of the CINECA area and other upwelling regions. Rapp P-V Cons Int Explor Mer 180: $323-334$

Thiel $\mathrm{H}$ (1983) Meiobenthos and nanobenthos of the deepsea. In: Rowe GT (ed) Deep-sea biology. John Wiley \& Sons, New York, p 167-230

Thurston MH, Bett BJ, Rice AL, Jackson PAB (1994) Variations in the invertebrate abyssal megafauna in the North Atlantic Ocean. Deep-Sea Res I 41:1321-1348

Thurston MH, Rice AL, Bett BJ (1998) Latitudinal variation in invertebrate megafaunal abundance and biomass in the North Atlantic Ocean Abyss. Deep-Sea Res II 45:203-224

Vangriesheim A (1995) Programme France-JGOFS. Projet EUMELI. Campagnes Eumeli 2 à Eumeli 5: Rapport des données de physique des mouillages benthiques à long terme (courants, néphélométrie). Rapport interne IFREMER DRO/EP 95/070-AV

Vanreusel A, Vincx M, Bett BJ, Rice AL (1995) Nematode biomass spectra at two abyssal sites in the NE Atlantic with a contrasting food supply. Int Rev Ges Hydrobiol 80:287-296

Vincx M, Bett BJ, Dinet A, Ferrero T, Gooday AJ, Lambshead PJD, Piannkuche O, Soltwedel T, Vanreusel A (1994) Meiobenthos of the deep northeast Atlantic. Adv Mar Biol 30: $2-88$

Vinogradov AP (1953) The elementary chemical composition of marine organisms. Sears Foundation for Marine Research, Yale University, New Haven

Vitiello P, Dinet A (1979) Définition et échantillonnage de méiobenthos. Rapp P-V Cons Int Explor Mer 25/26: $279-283$

Zibrowius H (1985) Scléractiniaires bathyaux et abyssaux de l'Atlantique nord-oriental: campagnes Biogas (Polygas) et Incal. In: Laubier L, Monniot C (eds) Peuplements profonds du Golfe de Gascogne. IFREMER, Paris, p 311-324

Submitted: January 6, 1999; Accepted: October 20, 1999

Proofs received from author(s): April 17, 2000 